\title{
Can InTERnational LaW HelP Resolve the Conflicts Over UNINHABITED ISLANDS IN THE EAST CHINA SEA?
}

\author{
MichAEL C. DAVIS ${ }^{*}$
}

\section{INTRODUCTION}

Former Chinese leader Deng Xiaoping once famously urged that resolution of disputes with China's neighbors over uninhabited islands be put off to a later generation, stating: "Our generation is not wise enough to find common language on this question. The next generation will certainly be wiser." ${ }^{1}$ Such sage advice seemed practical at the time, freeing China and its neighbors to focus on more pressing trade and economic development efforts. The wisdom of continuing deferral of the disputes over uninhabited islands is now in doubt, at least when peaceful alternatives may be considered. Beyond the rapid economic development and the consequent explosion of resource demands that has occurred since Deng uttered these words, technological development has made these deep seabed resources more readily accessible. ${ }^{2}$ Added to this has been China's rapid economic development and associated military rise, encouraging China's expanded attention to territorial sovereignty and resource claims in its periphery. ${ }^{3}$ Increased military confrontations over disputed islands have added to the urgency of this matter, and an impasse has prevailed. ${ }^{4}$

* University of Hong Kong, Faculty of Law (mcdavis@ @ku.hk).

1. Chien-Peng Chung, Domestic Politics, International Bargaining and China's Territorial Disputes 38 (2004); see also Chi-KIn Lo, China's Policy Toward Territorial Disputes: THE CASE OF THE SOUTH CHINA SEA ISLANDS 171 (2003).

2. U.S. Energy Info. Admin., EASt China SEA 1 (Sept. 17, 2014), available at http://www.eia.gov/countries/analysisbriefs/east_china_sea/east_china_sea.pdf (stating although the East China Sea may have abundant oil and natural gas resources, unresolved territorial disputes continue to hinder exploration and development in the area); Michael T. Klare, Island Grabbing in Asia: Why the South China Seas are So Tense, ForeIGn AfF. (Sept. 4, 2012), http://www.foreignaffairs.com/articles/138093/michael-t-klare/island-grabbing-in-asia.

3. Asia's Balance of Power: China's Military Rise, ECONOMIST, Apr. 7, 2012, http://www.economist.com/node/21552212; Toshi Yoshihara, War By Other Means: China's Political Uses of Seapower, DiPlomat (Sept. 26, 2012), http://thediplomat.com/2012/09/26/war-by-othermeans-chinas-political-uses-of-seapower; Kurt Campbell, Trouble at Sea Reveals the New Shape of China's Foreign Policy, FIN. TIMES, July 22, 2014, http://blogs.ft.com/the-a-list/2014/07/22/trouble-atsea-reveals-the-new-shape-of-chinas-foreign-policy.

4. Japan Defense Paper Warns of China's 'Dangerous Acts' in Sea, Air, Times India, Aug. 5, 2014, http://timesofindia.indiatimes.com/world/rest-of-world/Japan-defence-paper-warns-over-Chinasdangerous-acts-in-sea-air/articleshow/39663923.cms; Chinese Ships Advance in Waters Near Diaoyus Defying Japan's White Paper Warning, S. ChINA MoRnING Post, Aug. 6, 2014, 2:03 PM, http://www.scmp.com/news/asia/article/1567585/defying-japans-warning-chinese-ships-advancewaters-near-diaoyus. 
This article focuses on comparable disputes over two groups of uninhabited islands - the Dokdo (Takeshima in Japanese) Islands and the Diaoyu (Senkaku in Japanese) Islands - that may be pivotal to unraveling a series of volatile maritime disputes between Japan and South Korea, on the one hand, and Japan and China, on the other. The Dokdo/Takeshima and Senkaku/Diaoyu Islands are located respectively in the Sea of Japan (known as the East Sea in Korea) and the East China Sea. This narrowing of the topic to these two particular island disputes and related maritime issues is offered in the hope that these two sets of disputes may hold some keys to the wider, more factually complex debate stretching across the region, both north to the Yellow Sea and south to the South China Sea. ${ }^{5}$ At the same time, there is hope the Japan-South Korea dispute may inform options available for the China-Japan dispute.

In the face of the current impasse, the challenge is to identify those aspects of these island disputes that can be solved so as to ultimately facilitate more comprehensive maritime solutions that may be achieved under the United Nations Convention on the Law of the Sea ("UNCLOS"). " Toward this end, the following six sections will discuss: first, the posture of the current disputes; second, some international legal principles of relevance to the parties positions regarding territorial claims to uninhabited islands and resource rights in adjoining seas; third, the above-noted Japanese-South Korean dispute relating to the Dokdo/Takeshima Islands; fourth, the Sino-Japanese dispute over the Senkaku/Diaoyu Islands; fifth, the parties' positions regarding the related resource boundary claims; and, sixth, concluding recommendations on how best to move past the current impasse. Paradoxically, while resource concerns triggered a lot of the recent attention to these disputes, nationalistic concerns over sovereignty engender more passion in the disputants. The twin concern over sovereignty and resources has become an increasing cause of conflict in the Asian region, making settlement of resource claims without addressing the underlying sovereignty dispute increasingly difficult.

5. See generally Andy Yee, Maritime Territorial Disputes in East Asia: A Comparative Analysis of the South China Sea and the East China Sea, 2 J. CuRRENT ChINESE AFF. 165 (2011). Both Japan and South Korea have other sea resource boundary disputes with China. See e.g., Euan Graham, South Korea's Maritime Challenges: Between a Rock and a Hard Base, RSIS COMMENTARIES, No. 063/2012, Apr. 11, 2012, available at http://www.rsis.edu.sg/wp-content/uploads/2014/07/CO12063.pdf. The Sino-Korean dispute over Leo Island (actually submerged rocks) has been especially contentious. Terence Roehrig, South Korea-China Maritime Disputes: Toward a Solution, EASTASIAFORUM.ORG, Nov. 27, 2012, http://www.eastasiaforum.org/2012/11/27/south-korea-china-maritime-disputes-towarda-solution; China Must Not Take Its Territorial Ambitions Too Far, CHosun ILBo, Sept. 26, 2012, http://english.chosun.com/site/data/html_dir/2012/09/26/2012092601283.html; Scores of Chinese Fishing Boats Invade Korean Waters, ChOsun IlBO, May 2, 2014,http://english.chosun.com/site/data/html_dir/2014/05/02/2014050201344.html. Less relevant to the present discussion are Japanese disputes with Russia over its northern Kuril Islands. Japan PM, Putin Seek Progress on Islands Dispute, ABC News Austl., Apr. 29, 2013, http://www.abc.net.au/news/2013-04-29/an-japan2c-russia-discuss-islands-dispute/4658814.

6. See generally United Nations Convention on the Law of the Sea, Dec. 10, 1982, 1833 U.N.T.S. 3 [hereinafter UNCLOS]. 
With this in mind, the final section offers a recommendation that reverses both Deng Xiaoping's earlier sage advice and the favored international practice under UNCLOS of interim resource settlements in the face of intractable territorial disputes. Developing international customary law regarding claims to uninhabited islands suggests the most effective avenue to unraveling these territorial and maritime resource disputes is to first pay attention to peaceful resolution of the island and related maritime sovereignty disputes. In the spirit of the gentle removal of logs from the log-jam that characterizes these disputes, this effort might ideally begin with third-party dispute resolution, preferably in the International Court of Justice ("ICJ").

Careful consideration of the security and other alliances between South Korea and Japan, as they react to China's rise and North Korea's aggression, may encourage a process to resolve historical tensions and begin to outline relative rights respecting these islands and the broader maritime claims. Beyond such optimal approach, other lesser alternatives are also considered. These recommendations recognize attempts to fully resolve the maritime resource disputes have been held up for decades. Uncertainty over the islands' claims and associated resource zones has spawned the back and forth posturing that inhibits compromise over the maritime resource claims. The goal is to move the process forward toward a solution before the more aggravated military conflict, which many fear, ensues.

\section{The CURRENT Posture OF THE DiSPUTES}

\section{A. Tit-for-Tat Provocations}

The past couple of years have witnessed an explosion of confrontations relating to sovereignty and jurisdiction over uninhabited islands and maritime resource zones in the East and Southeast Asian maritime areas. The long list of confrontations between the parties to the present discussion have included: the Sino-Japanese dispute in late 2010 over the Japanese arrest of Chinese fishermen accused of ramming a Japanese patrol boat near the Japanese-administered Senkaku/Diaoyu Islands in the East China Sea; ${ }^{7}$ the 2012 Japanese arrest and quick release of fourteen Chinese civilians attempting to occupy Diaoyu/Senkaku, with follow-on Japanese civilian occupation; ${ }^{8}$ the September 2012 Japanese purchase of the Diaoyu/Senkaku Islands from a private Japanese holder (characterized by China as "nationalization"), which netted the largest anti-Japanese riots in China in decades ${ }^{9}$ Chinese patrol boats frequently confronting the Japanese Coast Guard

7. Japan-China Row over Ship Seizure, ALJAZEERA (Sept. 9, 2010, 9:48 AM), http://www.aljazeera.com/news/asia-pacific/2010/09/20109963630504649.html.

8. Martin Fackler, Japan Holds 14 Chinese in Island Landing, N.Y. Times, Aug. 15, 2012, http://www.nytimes.com/2012/08/16/world/asia/japanese-ministers-visit-tokyo-shrine.html?_r=0.

9. The Chinese government appears to manage the public discontent over Japan's purchase, first turning it on and then turning it off, perhaps fearing a backlash against their own government. Keith Bradsher, Martin Fackler, \& Andrew Jacobs, Anti-Japan Protests Erupt in China over Disputed Island, N.Y. TIMES, Aug. 19, 2012, http://www.nytimes.com/2012/08/20/world/asia/japanese-activists-display- 
off Diaoyu/Senkaku; ${ }^{10}$ various threats of sanctions (under WTO "security exceptions") or even war in the Chinese official press; ${ }^{11}$ Japan's scrambling of fighter planes in response to Chinese warplanes flying near the Senkaku/Diaoyu Islands. $^{12}$

That there has been a similar list of disputes in the South China Sea signals that the reach of this tense situation goes well beyond the immediate area to include: maritime patrol boat confrontations between China and its neighbors over the Spratly and Paracel Islands in the South China Sea; ${ }^{13}$ disputes in 2014 over a Chinese drilling platform operating in waters generally thought to be in the Vietnamese Exclusive Economic Zone ("EEZ"), netting confrontations at sea and large Vietnamese street protest; ${ }^{14}$ a dispute and then a now-failed compromise between the Philippines and China over Scarborough Shoal and China's building of man-made islands on reefs in the disputed Spratly Islands. ${ }^{15}$ While the present essay will discuss prominent East China Sea disputes, those in the South China Sea are equally compelling.

Any of these disputes risk conflagration across the region as various security alignments are brought into play. Recent developments, with China employing

flag-on-disputed-island.html?hp (noting the demonstrations appeared sanctioned and chaperoned by police). While Beijing accuses Japan of provoking China by nationalizing the Senkaku/Diaoyu islands, it appears the Japanese purchase from private owners was designed to avoid a purchase being orchestrated by the more nationalistic Tokyo governor. Mari Yamaguchi, Tokyo Governor Says City will Buy Disputed Islands, AsSOCIATED PRESS, Apr. 17, 2012, http://finance.yahoo.com/news/tokyogovernor-says-city-buy-150303483.html. See also Ed Zhang, China Lays into Japan over Naming of

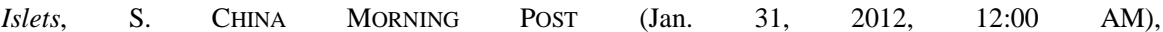
http://www.scmp.com/article/991303/china-lays-japan-over-naming-islets.

10. Minnie Chan, PLA Puts Military Heat on Japan over Diaoyu Islands, S. ChINA MoRnING Post (Sept. 12, 2012, 7:11 PM), http://www.scmp.com/news/china/article/1035320/pla-puts-militaryheat-japan-over-diaoyu-islands.

11. Jin Baisong, Consider Sanctions on Japan, ChINA DAILY, Sept. 17, 2012, 7:53 AM), http://www.chinadaily.com.cn/opinion/2012-09/17/content_15761435.htm (indicating a military response should be a last choice); Jane Perlez, China Alters Its Strategy in Diplomatic Crisis with Japan, N.Y. TimeS, Sept. 28, 2012, http://www.nytimes.com/2012/09/29/world/asia/china-alters-itsstrategy-in-dispute-with-japan.html?pagewanted=all\&_r=0.

12. Julian Ryall, Japanese Jets Ordered to Diaoyus 160 Times in Nine Months, S. CHINA MoRnING POST, Jan. 26, 2013, 6:10 PM, http://www.scmp.com/news/china/article/1136249/japanesejets-ordered-diaoyus-160-times-nine-months.

13. Ian Storey, ASEAN and the South China Sea: Movement in Lieu of Progress, CHINA BRIEF, Apr. 26, 2012, at $10, \quad$ available at http://www.jamestown.org/single/?tx_ttnews\%5Btt_news\%5D=39305\&tx_ttnews\%5BbackPid\%5D=58 9\&no_cache=1\#.VFrdufnF_Xt.

14. Edward Wong, Analysts Say China May Try to Use Manmade Islands to Bolster Bid for $\begin{array}{lllll}\text { Economic Development, N.Y. TIMES, June 19, } & \text { 2014, }\end{array}$ http://sinosphere.blogs.nytimes.com/2014/06/19/analysts-say-china-may-try-to-use-manmade-islandsto-bolster-bid-for-economic-development/; NGUYen Thi LAN ANH, XISHA (PARACEL) ISLANDS: A REJOINDER (2014), available at http://www.rsis.edu.sg/wp-content/uploads/2014/07/CO14117.pdf.

15. Kristine Kwok \& Minnie Chan, China Plans Artificial Island in Disputed Spratlys Chain in

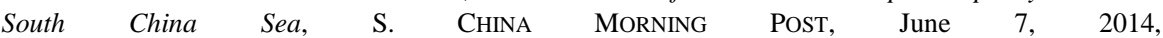
http://www.scmp.com/news/china/article/1527059/china-plans-artificial-island-disputed-spratlys-chainsouth-china-sea?page=all. 
drones near the Diaoyu/Senkaku Islands and declaring an Air Defense Identification Zone ("ADIZ") to overlap the Japanese controlled islands, have raised ominous concerns about miscalculations leading to military conflict. ${ }^{16}$ Chinese officials and commentators have invoked World War II history to suggest a rising tide of Japanese militarism. ${ }^{17}$ The perceived threat from a now rising China may appear more imminent to its neighbors.

A common thread in many of these disputes is China's military rise and consequent assertiveness. ${ }^{18}$ There have been threatening domestic calls for China to enhance its sea power in order to deal more forcefully with these challenges. ${ }^{19}$ These have included what has been called a "near sea doctrine" China announced five years ago, where China declared an aim to exercise greater control over the East and South China Seas. ${ }^{20}$ There have in fact been several incursions by

16. Christopher Bodeen, China Warns Foreign Planes Entering Defense Zone, AssociATED PRESS, Jan. 24, 2014, http://news.yahoo.com/china-warns-foreign-planes-entering-defense-zone064540562.html; Wendell Minnick, Fact Sheet: China's Air Defense Zone, DeFENSE NEws, Nov. 2, 2013, http://www.defensenews.com/article/20131124/DEFREG03/311240004/Fact-Sheet-China-s-AirDefense-Zone; US Criticizes New China Zone, Vows to Defend Japan, SPACEWAR.COM, Nov. 23, 2013, http://www.spacewar.com/reports/US_criticizes_new_China_zone_vows_to_defend_Japan_999.html; Press Release, Ministry of Nat'l Def., PRC, Defense Spokesman Yang Yujun's Response to Questions on the Establishment of the East China Sea Air Defense Identification Zone (Nov. 23, 2013), available at http://eng.mod.gov.cn/TopNews/2013-11/23/content_4476149.htm; Chris Buckley, China Claims Air Rights over Disputed Islands, N.Y. TIMES, Nov. 23, 2013, http://www.nytimes.com/2013/11/24/world/asia/china-warns-of-action-against-aircraft-over-disputedseas.html?_r=0; Former Chinese Commander Warns of War If Japan Shoots Down Drone, BLOOMBERG News, Nov. 4, 2013, http://www.bloomberg.com/news/2013-11-04/former-chinesecommander-warns-of-war-if-japan-shoots-down-drone.html; Martin Fackler, Japan Rejects China's Claim to Air Rights Over Islands, N.Y. TIMES, Nov. 24, 2013, http://www.nytimes.com/2013/11/25/world/asia/japan-rejects-chinas-claim-to-air-rights-over-disputedislands.html?ref=international-home; Ely Ratner, China Undeterred and Unapologetic, WARONTHEROCKS.COM, June 24, 2014, http://warontherocks.com/2014/06/china-undeterred-andunapologetic/.

17. Zhang Junsai, Abe's Militarism Defies History, Globe AND MaIL, Jan. 9, 2014, http://www.theglobeandmail.com/globe-debate/abes-militarism-defies-history/article16244968/.

18. Edward Wong, China Navy Reaches Far, Unsettling the Region, N.Y. TimES, June 15, 2011, http://www.nytimes.com/2011/06/15/world/asia/15china.html?_r=0; Asia's Balance of Power, supra note 3; China's Maritime Ambitions Making Waves in Pacific, PHIL. DAILY INQUIRER, Aug. 10, 2013, 3:35 AM, http://globalnation.inquirer.net/82919/chinas-maritime-ambitions-making-waves-in-pacific2/. China's inclusion of the islands among its "core interest" has also caused unease. China Officially Labels Senkakus a 'Core Interest', JAPAN TIMES, Apr. 27, 2013, http://www.japantimes.co.jp/news/2013/04/27/national/china-officially-labels-senkakus-a-coreinterest/\#.VF0B3_nF_Vo; Senkakus a 'Core Interest,' Chinese Military Scholar Tells Japan, JAPAN TiMES, Aug. 20, 2013, http://www.japantimes.co.jp/news/2013/08/20/national/politicsdiplomacy/senkakus-a-core-interest-chinese-military-scholar-tells-japan/\#.VF0EO_nF_Vp; Phillip C. Saunders, China's Juggling Act: Balancing Stability and Territorial Claims, PACNET No. 33 (Center for Strategic \& Int'l Studies), Apr. 29, 2014, at 1, available at http://csis.org/files/publication/Pac1433.pdf.

19. Hao Zhou, China Yet to be a Sea Power, GlobalTimes.Cn, Mar. 23, 2012, http://www.globaltimes.cn/content/701700.shtml.

20. Michael J. Green, Negotiating Asia's Troubled Waters, N.Y. TimES, Apr. 23, 2013, http://www.nytimes.com/2014/04/24/opinion/negotiating-asias-troubled-waters.html?_r=0. 
Chinese Coast Guard, marine surveillance ships, and aircrafts near these islands and others in the South China Sea. ${ }^{21}$ A prominent Japanese retired admiral has even argued, beyond seabed resource claims, China's real goal in seeking to control the Senkaku/Diaoyu Islands and the South China Sea is to create a submarine safe-zone in the South China Sea to enhance unfettered access to the open ocean by nuclear submarines, as a deterrent against the U.S. ${ }^{22}$ Others take the view that China is simply in a renewal phase aimed at expanding its sovereign territory and resurrecting its more glorious past. ${ }^{23}$ Whichever theory is correct, China's military posturing raises risks both for the disputants and for U.S. involvement. $^{24}$ Concerns about full civilian control of China's military have enhanced the perceived sense of risk in military encounters at sea. ${ }^{25}$ Diplomatic efforts to contain this risk have born very little fruit. ${ }^{26}$

These risks have also produced escalation on the Japanese side. After years of somewhat stagnant military budgets, Japan has announced defense budget increases and strategic shifts to counter Chinese incursions. ${ }^{27}$ It has revised its

21. China's New Coastguard Flexes Muscles near Diaoyu Islands, S. CHINA MoRning Post, July 26, 2013, http://www.scmp.com/news/china/article/1291292/chinese-coastguard-enters-japanesecontrolled-waters-raising-tensions; Three Chinese Vessels Enter Territorial Waters Near Senkakus, JAPAN TIMES, Feb. 28, 2013, http://www.japantimes.co.jp/news/2013/02/28/national/three-chinesevessels-enter-territorial-waters-near-senkakus/\#.VF0fUPnF_Vo; Barbara Demick, China Wages Stealth War in Asian Waters, L.A. TIMES, Mar. 27, 2013, http://articles.latimes.com/2013/mar/27/world/la-fgchina-maritime-20130327; Japan PM Abe Warns China of Force Over Islands Landing, BBC NEWS, Apr. 23, 2013, http://www.bbc.com/news/world-asia-22260140.

22. Reiji Yoshida, Beijing's Senkaku Goal: Sub 'Safe Haven' in South China Sea, JAPAN TIMES, Nov. 7, 2012, http://www.japantimes.co.jp/news/2012/11/07/national/beijings-senkaku-goal-sub-safehaven-in-south-china-sea/.

23. John Lee, China's Dream of Rebirth, S. ChINA Morning Post, Mar. 2, 2013, http://www.scmp.com/comment/insight-opinion/article/1166737/chinas-dream-rebirth?page=all; Holly Morrow, It's Not About the Oil-It's About the Tiny Rocks, ForEIGN POL'Y, Aug. 4, 2014, http://www.foreignpolicy.com/articles/2014/08/04/it_s_not_about_the_oil_it_s_about_the_tiny_rocks_c hina_south_china_sea_japan_vietnam (arguing that these disputes are not about oil but are primarily about sovereignty)

24. John Pomfret, Japan and China's Island Argument is a U.S. Concern, WASH. Post, Feb. 5, 2013, http://www.washingtonpost.com/opinions/japan-and-chinas-island-argument-is-a-usconcern/2013/02/05/fbc7ed62-6999-11e2-af53-7b2b2a7510a8_story.html; U.S. Airs Concern over China's Radar Locking on Japanese Defense Ship, ASIA NEwS MONITOR, Feb. 7, 2013; Insight: China Increased Belligerence after U.S. Aircraft Deployment near Senkakus, ASAHI SHIMBUN, Feb. 6, 2013, http://ajw.asahi.com/article/asia/AJ201302060077.

25. Masahiro Matsumura, Praetorian China?, PROJECT-SYNDICATE.ORG (Apr. 26, 2013), http://www.project-syndicate.org/commentary/china-s-loss-of-civilian-control-over-the-military-bymasahiro-matsumura.

26. Showing Off to the World, ECONOMIST, Nov. 8, 2014, http://www.economist.com/news/china/21631107-capital-about-host-president-xi-jinpings-diplomaticcoming-out-party-showing.

27. Yuka Hayashi, Japanese General Seeks to Reinforce Defenses, WALL ST. J., Jan. 14, 2013, http://online.wsj.com/articles/SB10001424127887324581504578238473997165346; see generally JAPAN MINISTRY OF DEFENSE, DEFENSE OF JAPAN 2013 (2013), available at http://www.mod.go.jp/e/publ/w_paper/2013.html) (reflecting a shift in defense interest from the North to the islands in the Southwest). 
defense strategy to focus its forces more to the south to defend against potential Chinese attacks on its islands. ${ }^{28}$ Japan has also stepped up efforts to develop a stealth fighter jet to match the J-20 stealth fighter recently tested by China. ${ }^{29}$ Japan has engaged in war games and placed missiles on nearby Pacific gateway islands. ${ }^{30}$ It has also attempted to contain the problem by reaching a separate agreement with the Republic of China ("ROC") to allow Taiwanese fishermen to fish near the Senkaku/Diaoyu Islands just beyond the twelve-mile territorial sea boundary. ${ }^{31}$

Some disputants have lodged formal protests or other submissions to the United Nations. In Southeast Asia, these complaints relate to China's allegedly excessive resource claims and the so-called "nine dotted lines" claim to most of the South China Sea. ${ }^{32}$ China has reacted to the most aggressive of these, relating to the filing by the Philippines, by refusing to participate and put forth its own arbitrator, requiring the President of the U.N. Tribunal to select a judge on behalf of China. ${ }^{33}$ After the 2012 Diaoyu/Senkaku crises, China instituted its own filing

28. See Hayashi, supra note 27.

29. David Axe, Japan's Stealth Fighter Gambit, DiPlomAT, June 23, 2011, http://thediplomat.com/2011/06/japans-stealth-fighter-gambit/?allpages=yes.

30. Japan putting Missiles on Pacific Gateway Islands, CHANNELNEWSASIA.COM, Nov. 7, 2013, http://www.channelnewsasia.com/news/specialreports/mh370/news/japan-putting-missileson/878190.html.

31. China Angered as Japan, Taiwan Sign Fishing Agreement, REUTERS, Apr. 10, 2013, http://www.reuters.com/article/2013/04/10/us-china-japan-taiwan-idUSBRE93909520130410; Minnie Chan, Taiwan Would 'Expel' Mainland Trawlers under Japan Fishing Deal, S. CHINA MoRNING PosT, Apr. 10, 2013, http://www.scmp.com/news/china/article/1211568/china-angered-japan-taiwan-signfishing-agreement?page $=$ all.

32. Though China has formally opted out of compulsory jurisdiction for maritime boundaries and military activities, as permitted under UNCLOS, the Philippines has filed a claim under UNCLOS to Scarborough Shoal (known as Huangyan Island in China). China Rejects Manila Claims over South China Shoal, Associated PRESS, Apr. 18, 2012, http://seattletimes.com/html/nationworld/2018004165_apassouthchinasea.html. Beyond these island disputes there are numerous issues related to China's hotly disputed claims to nearly all of the South China Seas within the infamous "nine dotted lines", which Wang Gungwu traces to China's attempted accession of Japanese imperial claims following World War II. Wang Gungwu, China and the Map of Nine Dotted Lines, STRAITS TIMES, July 11, 2012, http://www.straitstimes.com/the-big-story/asiareport/china/story/china-and-the-map-nine-dotted-lines-20120711.

33. Greg Torode, For South China Sea Claimants, a Legal Venue to Battle China, REUTERS, Feb. 12, 2014, http://www.reuters.com/article/2014/02/13/us-china-vietnam-idUSBREA1C04R20140213. The arbitration judicial panel was fully constituted on April 24, 2013, to include judges from Sri Lanka (president), France, Germany, Netherlands, and Poland. See Greg Torode, Manila to Tackle Sea Row 'With or Without China' at UN, S. CHINA MORNING PosT, Feb. 21, 2013, http://www.scmp.com/news/asia/article/1154951/manila-tackle-sea-row-or-without-china-un; Verna Yu, Beijing Looks Like A 'Bully' By Refusing Arbitration of South China Sea, S. CHINA MoRNING POST, May 25, 2013, http://www.scmp.com/news/china/article/1245471/beijing-looks-bully-rejectingarbitration-south-china-sea-issue; Raissa Robles, Philippines Seeks UN arbitration over South China Sea Disputes, S. CHINA MoRNING Post, May 11, 2013, http://www.scmp.com/news/asia/article/1234952/philippines-seeks-un-arbitration-over-south-china-seadisputes. The arbitration is expected to take several years, leaving further opportunity to attempt settlement. China has refused to appear, though the tribunal is going forward. Beijing Rejects Tribunal Request for Plea Response, TAIPEI TIMES, June 5, 2014, http://www.taipeitimes.com/News/front/archives/2014/06/05/2003592024. Though not formally 
with the U.N., indicating its base points and strait baselines to claim territorial seas and possibly associated resource zones for the disputed islands. ${ }^{34}$ China has since proclaimed its intention to patrol claimed areas now under the administration of other states. ${ }^{35}$ Such Chinese proclamations have included reported regulations on vessels in China's territorial seas, issued by the responsible Hainan People's Congress. $^{36}$ It has been argued that enforcement of such regulations through seizure of a foreign vessel may open China up to the compulsory jurisdiction of the International Tribunal of the Law of the Sea ("ITLOS"), which has disavowed jurisdiction in maritime delimitation disputes. ${ }^{37}$ These official Chinese actions, in conjunction with official encouragement of anti-Japanese demonstrations, not to mention encouragement for Chinese fishing and patrol vessels to enter the disputed areas, surely contribute to a volatile situation. ${ }^{38}$

appearing, China did publish a position paper objecting to jurisdiction in the dispute on December 7, 2014. Position PAPER of the Government of the People's RePublic of

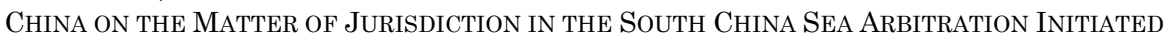
BY THE REPUBLIC OF THE PHILIPPINES (2014), available at http://www.fmprc.gov.cn/mfa_eng/zxxx_662805/t1217147.shtml.

34. Government of the PRC, Government SUbmission to THE U.N., Statement of the Government of the PRC on the Baselines of the Territorial Sea of Diaoyu Dao and Its Affiliated Islands (Sept. 10, 2012), available at http://www.un.org/depts/los/LEGISLATIONANDTREATIES/PDFFILES/DEPOSIT/chn_mzn89_2012 _e.pdf; China's Statement over Diaoyu Islands, PeOPle's DAILY, Sept. 11, 2012, http://english.people.com.cn/90883/7943813.html; Continental Shelf Notification, U.N. DOALOS, Receipt of the Submission Made by the People's Republic of China to the Commission on the Limits of the Continental Shelf, CLCS.63.2012LOS (Dec. 14, 2012), available at http://www.un.org/depts/los/clcs_new/submissions_files/chn63_12/clcs_63_2012.pdf. Base lines refer to the inland boundary of the territorial sea from which all other zones are measured; when coast are uneven or for islands strait baselines may be used under certain conditions. See J. Ashley Roach, China 's Straight Baseline Claim: Senkaku (Diaoyu) Islands, 17 AM. Soc'Y INT'L L. 1 (2013), available at http://www.asil.org/insights/volume/17/issue/7/china\%E2\%80\%99s-straight-baseline-claim-senkakudiaoyu-islands. UNCLOS Article 5 provides, "except where otherwise provided in this Convention, the normal baseline for measuring the breadth of the territorial sea is the low-water line along the coast as marked on large-scale charts officially recognized by the coastal State." UNCLOS Article 7 allows for strait baselines, (1) "in localities where the coastline is deeply indented and cut into," and (2) "if there is a fringe of islands along the coast in its immediate vicinity." UNCLOS Article 46 allows strait baselines for archipelagic states to outer most islands.

35. Stephanie Kleine-Ahlbrandt, Dangerous Waters, Why China's Dispute with Japan is More Dangerous than You Think, FOREIGN POL'Y, Sept. 17, 2012, http://www.foreignpolicy.com/articles/2012/09/17/dangerous_waters.

36. See, e.g., H.R. Res. 776, 113th Cong. \$2(27) (2013).

37. Ben Blanchard \& Manuel Mogato, Chinese Police Plan to Board Vessels in Disputed Seas, REUTERS, Nov. 29, 2012, http://www.reuters.com/article/2012/11/29/us-china-seasidUSBRE8AS05E20121129. Sam Bateman argues that although China has opted out of compulsory jurisdiction for maritime delimitation, it seizure of a vessel in contested waters claimed as territorial waters in a seizure dispute could open the door to the boundary delimitation issues necessary to determine the appropriateness of the seizure. Sam Bateman, China's New Maritime Regulations: Do They Accord with International Law?, RSIS COMMENTARIES, No. 220/2012, Dec. 5, 2012, available at http://www.rsis.edu.sg/wp-content/uploads/2014/07/CO12220.pdf.

38. Minnie Chan, China Vows to Protect 2,000 Fishing Boats Heading Towards Diaoyus, S. ChINA MoRNing Post, Sept. 18, 2012, http://www.scmp.com/news/china/article/1039353/china-vows- 
The discussion of these maritime disputes in several international forums signals enhanced likelihood of further confrontation. Discussions at the March 2012 meeting of China's National People's Congress tended to show China's determination to press its maritime claims with even greater determination. ${ }^{39}$ As President Obama restated in Tokyo in April 2014, the U.S. is committed to defend Diaoyu/Senkaku under the U.S.-Japan Treaty of Mutual Cooperation and Security. ${ }^{40}$ This frequently stated commitment, endorsed by congressional resolution in late 2012, no doubt contributes to the military risk associated with this issue. ${ }^{41}$ Japan's hedging against China's volatile threats also includes increased security alignments with other threatened states. ${ }^{42}$ While there have

protect-2000-fishing-boats-heading-towards-diaoyus. There has generally been less agitation on the Japanese side. Julian Ryall, Japanese Unmoved by Diaoyus Row, S. ChInA MoRnING Post, Sept. 18, 2012, http://www.scmp.com/news/china/article/1039350/japanese-unmoved-diaoyus-row?page=all. That Beijing frequently employs a people's war strategy of using ostensibly private fishing boats for quasi-military purposes as "fisheries patrols" off Senkaku/Diaoyu poses a particular risk of military confrontation. Will Clem, Use Fisheries Patrols to Tighten Grip on Diaoyus, Official Says, S. ChINA MoRnING POST, Dec. 7, 2010, http://www.scmp.com/article/732654/use-fisheries-patrols-tighten-gripdiaoyus-official-says; Mark McDonald, Will China Arm its Fishermen to Protect a 'Core Interest'?, N.Y. TIMES, Sept. 12, 2012, http://rendezvous.blogs.nytimes.com/2012/09/12/will-china-arm-itsfishermen-to-protect-a-core-interest/?_r=0. Beyond military tensions there have even been civilian boycotts of Japanese goods. Ben Blanchard \& Xiaoyi Shao, China Says Tensions with Japan Likely to Hurt Trade, REUTERS, Sept. 13, 2012, http://www.reuters.com/article/2012/09/13/us-china-japanidUSBRE88C04620120913; Edward Wong, China's Hard Line: 'No Room for Compromise', N.Y. TIMES, Mar. 8, 2014, http://www.nytimes.com/2014/03/09/world/asia/china.html.

39. Li Mingiiang, China's Rising Maritime Aspirations: Impact on Beijing's Good-Neighbour Policy, RSIS COMMENTARIES, No. 053/2012, Mar. 28, 2012, available at http://www.rsis.edu.sg/wpcontent/uploads/2014/07/CO12053.pdf.

40. Kristine Kwok, Obama Reassures Japan over Diaoyu Islands, but Warns Against Provoking China, S. ChINA MORNING Post, Apr. 24, 2014, http://www.scmp.com/news/asia/article/1496261/obama-reassures-japan-over-islands-warns-againstprovoking-china?page=all.

41. Hitoshi Tanaka, Politicizing the SenKaku Islands: A Danger to Regional Stability 2 (2012), available at http://www.jcie.org/researchpdfs/EAI/7-3.pdf. This defense treaty coverage was emphasized again in early 2013. Atsushi Matsuura, Clinton Sends Warning to China over Senkakus, YOMIURI SHIMBUN (Jan. 21, 2013, 5:51 PM), http://www.4thmedia.org/2013/01/china-stronglychallenges-us-comments-about-the-diaoyu-islands/. That the U.S. has also recently committed to increased missile defense for Japan and to deploy drones over the Diaoyu/Senkaku islands increases the military significance of these commitments. Thom Shanker \& Ian Johnson, US Accord with Japan over Missile Defense Draws Criticism in China, N.Y. TIMES, Sept. 17, 2012, http://www.nytimes.com/2012/09/18/world/asia/u-s-and-japan-agree-on-missile-defense-

system.html?ref=global-home. J. Michael Cole, US to Deploy Drones over Diaoyutais, TAIPEI TIMES, Aug. 8, 2012, http://www.taipeitimes.com/News/front/archives/2012/08/08/2003539722; US Backing May Prove Costly for Japan, GLOBAL TiMES, Sept. 16, 2012, http://www.globaltimes.cn/content/733451.shtml.

42. Japan, Vietnam to Deepen Security Ties Amid China's Growing Assertiveness, MAINICHI, Jan. 18 , 2013 https://web.archive.org/web/20130120053829/http:/mainichi.jp/english/english/newsselect/news/20130 117p2g00m0dm024000c.html; Isamu Nikaido \& Shinichi Sekine, Abe to Strengthen ASEAN Ties to Contain China's Maritime Advances, ASAHI SHIMBUN, Jan. 12, 2013, http://ajw.asahi.com/article/behind_news/politics/AJ201301120042; Robert A. Manning, Abe's ASEAN 
been calls to prepare for war on both sides, the majority opinion is that China and Japan will not risk an all-out war. ${ }^{43}$

Efforts to contain the dispute have also been evident. In August 2012, the Beijing government asked that the Japanese government follow "three no's": Japanese nationals should not land on the disputed islands, Japan should not develop resources around the island, and Japan should not construct any buildings on the islands. ${ }^{44}$ Internet users in China attacked the government for being weak. ${ }^{45}$ In late 2013, the Chinese Foreign Minister, Wang Yi, speaking before the U.N. General Assembly, sought to cool down these intense disputes by re-invoking Deng Xiaoping's famous dictum about the time not now being ripe to address these issues, though he insisted Japan at least acknowledge the dispute. ${ }^{46}$ In 2014 Washington, Manila, Beijing, and Tokyo backed a code of conduct to prevent conflict at sea that has tried to reduce the discussed risks by banning radar-locking of weaponry and setting out a reporting mechanism when naval vessels meet unexpectedly in sea lanes. ${ }^{47}$

The danger of Sino-Japanese military miscalculation has, nevertheless, become increasingly evident in the tit-for-tat military moves of both sides. China viewed the Japanese arrest of fishing boat captains in Japanese-claimed waters and the naming of the islands claimed by China as provocative. ${ }^{48}$ China has increased official patrols near the Diaoyu/Senkaku Islands, enhancing the risk of confrontation. $^{49}$ On two occasions, the Chinese were reported to have locked

Tour Stresses Regional Tension, GlobAL $\quad$ TimeS, Jan.
http://www.globaltimes.cn/content/756023.shtml.
43. Trefor Moss, High-stakes Stand-off Between Japan and China Won't Come to War, S. CHINA
MoRNING POST, Jan.17, 2013, http://www.scmp.com/comment/insight-opinion/article/1129510/highstakes-stand-between-japan-and-china-wont-come-war?page=all; Chi-yuk Choi, PLA Officials Say Troops are to Prepare for War Amid Territorial Disputes with Japan, S. CHINA MoRNING Post, Jan. 16, 2013, http://www.scmp.com/news/china/article/1128164/pla-officials-say-troops-are-prepare-waramid-territorial-disputes-japan.

44. Beijing to Issue "Three Nos" To Japan over Diaoyutais, WANT CHINA TiMES, Aug. 30, 2012, http://www.wantchinatimes.com/news-subclass-cnt.aspx id=20120830000089\&cid=1101.

45. Id.

46. Atsushi Okudera, Chinese Foreign Minister Takes to Japan in U.N. Speech, ASAHI SHIMBUN, Sept. 28, 2013, http://ajw.asahi.com/article/behind_news/politics/AJ201309280060.

47. Teddy Ng \& Julian Ryall, Beijing Backs Code to Prevent Conflict at Sea Along with US and Japan, S. CHINA Morning Post, Apr. http://www.scmp.com/news/china/article/1494736/china-among-21-nations-back-code-preventunintended-conflict-sea.

48. Ed Zhang, China Lays into Japan Over Naming of Islets, S. CHINA MoRning Post, Jan. 31, 2012, http://www.scmp.com/article/991303/china-lays-japan-over-naming-islets; Teddy Ng, New Maritime Clash Threatens Sino-Japan Ties, S. CHINA Morning Post, Nov. 8, 2011, http://www.scmp.com/article/984181/new-maritime-clash-threatens-sino-japan-ties; China's Contradictory Approach to Arrest of Fishermen, CHOSUN ILBO, Nov. 10, 2011, http://english.chosun.com/site/data/html_dir/2011/11/10/2011111001144.html.

49. Austin Ramzy, Tensions with Japan Increase as China Sends Patrol Boats to Disputed Islands, TIME, Sept. 14, 2012, http://world.time.com/2012/09/14/tensions-with-japan-increase-as-chinasends-patrol-boats-to-disputed-islands/. 
weapons-guiding radar on Japanese vessels, accompanied by Chinese denials. ${ }^{50}$ There have also been reports of China using drones to defend its claims in the East China Sea and reports of China's intentions to increase patrols even further, to which Japan is likewise preparing defensive measures. ${ }^{51}$

What started with the Japanese government reaching agreement with the private Japanese owners to buy and nationalize the islands, to head off plans of Japanese right-wing politicians, garnered a heated Chinese response and has escalated into the central dispute between these two trading partners. ${ }^{52}$ The Chinese government hardly appreciated the Japanese official's motive to undermine a purchase by the more right-wing Governor of Tokyo, who would surely have engaged in other provocative acts on the islands. ${ }^{53}$ China sometimes characterizes its claims in the South China Sea and the East China Sea as "core national interests," suggesting non-negotiability, which has carried a menacing tone. $^{54}$

50. Yuka Hayashi, US Commander Chides China Over Provocative Act, WALl ST. J., Feb. 16, 2013, http://online.wsj.com/articles/SB10001424127887324432004578305453572408918; Chris Buckley, China Denies Directing Radar at Japanese Military, N.Y. TIMES, Feb. 8, 2013, http://www.nytimes.com/2013/02/09/world/asia/china-denies-directing-radar-at-japanese-

military.html?_r=0.

51. Stephen Chen, Liaoning Sends Drones Over East China Sea, S. China Morning Post, Nov. 30, 2011, http://www.scmp.com/article/986333/liaoning-sends-drones-over-east-china-sea; Minnie Chan, Beijing's Patrol Missions Predicted to Rise, S. China Morning Post, Mar. 21, 2012, http://www.scmp.com/article/996069/beijing-patrol-missions-predicted-rise; Defense Ministry Working on Protocol to Shoot Down Encroaching Drones, ASAHI SHIMBun, Oct. 2, 2013, http://ajw.asahi.com/article/behind_news/politics/AJ201310020040.Ramzy, supra note 49.

52. Raymond Li, Papers Go Ballistic over Diaoyu Dispute with Japan Islands in a Storm of Rhetoric, with One Daily Suggesting 'Serving Main Course of Nuclear Missiles', S. China MoRning Post, Sept. 16, 2012, http://www.scmp.com/comment/insight-opinion/article/1037887/papers-goballistic-over-diaoyu-dispute-japan (China proclaiming the sale illegal and invalid); Shi Jingtao, $H u$ Warns Japan over Planned Purchase of Diaoyu Islands, S. ChinA MoRning Post, Sept. 10, 2012, http://www.scmp.com/news/china/article/1033054/hu-warns-japan-over-planned-purchase-diaoyuislands; Mure Dickie \& Kathrin Hille, Japan Risks China's Wrath over Senkakus, FIN. TimES, Sept. 10,

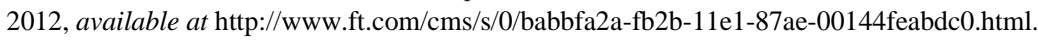

53. Malcolm Foster, Tokyo Governor Says City Plans to Buy Disputed East China Sea Islands, ASSOCIATED PRESS, Apr. 17, 2012, available at http://bigstory.ap.org/article/media-japan-govt-agreesbuy-disputed-islands. There have been reports that Japan had quietly notified China and tried to reach an understanding as to the need for this purchase, but ultimately to no avail. Japan, China Were Close to Preventing Current Turmoil Over Senkaku, ASAHI SHIMBUn, Oct. 22, 2013, http://ajw.asahi.com/article/behind_news/politics/AJ201310220059.

54. Chinese General Luo Yuan said, "Core interests are not for debate, not for negotiation, and not for trade off." This may say more about China efforts to aggressively assert its claims than reality since the Chinese have frequently negotiated over core interest issues such as Taiwan and Hong Kong. Ed Zhang, A Hawkish General with a Dove's Heart and Mind, S. China Morning Post, Mar. 16, 2011, http://www.scmp.com/article/741066/hawkish-general-doves-heart-and-mind; China Officially Labels

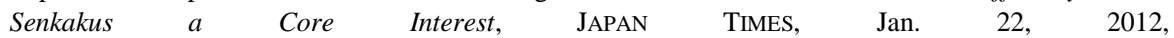
http://www.japantimes.co.jp/news/2013/04/27/national/china-officially-labels-senkakus-a-core-

interest/\#.VF6k1PTF8QQ; Cary Huang, A Bolder China Asserts 'Core Interests' -But Will It Act?, S. ChinA MoRning Post, Aug. 12, 2010, http://www.scmp.com/article/721928/bolder-china-asserts-coreinterests-will-it-act; Lanxin Xiang, Stumbling Block, S. ChinA MoRning Post, Nov. 26, 2010, http://www.scmp.com/article/731654/stumbling-block. 
While the Japanese dispute with South Korea over Dokdo/Takashima has been comparably less volatile, there have been tense moments and concern about Japan-Korean defense alignments. While Japan is in possession of Senkaku/Diaoyu, South Korea is in possession of Dokdo/Takeshima. ${ }^{55}$ The Japanese Government took a dim view of the South Korean President paying a personal visit to Dokdo/Takeshima. ${ }^{56}$ These South Korean initiatives have seemingly encouraged China to seek alignment with South Korea against Japan. ${ }^{57}$

These disputes have also reached beyond the immediate disputants, affecting the security posture throughout the region. The U.S. defense obligations towards Japan and South Korea along with tit-for-tat confrontations with China over U.S. warship passage through these seas have raised the temperature. ${ }^{58}$ Vietnam and the Philippines have beefed up their defenses in response to perceived Chinese provocations ${ }^{59}$ that all parties are increasingly likely to arrest the others' fishermen in claimed waters, which signals greater urgency across the region. ${ }^{60}$ The risk of hot war from continuing failure to resolve certain territorial and resource claims in the region is evident. Numerous efforts at discussion between the disputants have not so far produced results. ${ }^{61}$

55. Japan has administered the Senkaku Islands since the U.S. turned them over to Japan in conjunction with Okinawa in 1972. Ministry of Foreign Affairs Japan, Senkaku Islands Q\&A, June 5, 2013, available at http://www.mofa.go.jp/region/asia-paci/senkaku/qa_1010.html. South Korea has held Dokdo continuously since the end of the Korean War but has claims going back centuries. Steven J. Barber, Historical Facts about Korea's Dokdo Islands, Hist. FACTS ABOUT KoREA's DOKDO ISLAND, http://www.dokdo-takeshima.com (last visited Dec. 30, 2014).

56. Choe Sang-hun, South Korean's Visit to Disputed Island Angers Japan, N.Y. TIMES, Aug.10, 2012, http://www.nytimes.com/2012/08/11/world/asia/south-koreans-visit-to-disputed-islets-angersjapan.html?_r=0.

57. China Seeks Korea's Support in Territorial Claims, Chosun ILBO, Sept. 19, 2012, http://english.chosun.com/site/data/html_dir/2012/09/19/2012091901268.html.

58. Greg Torode, Arrival of U.S. Sub in Phillipines Sign of Shifting Balance of Naval Power, S. China Morning Post, Sept. 15, 2012, http://www.scmp.com/news/asia/article/1037174/arrival-ussub-philippines-sign-shifting-balance-naval-power. See, e.g., Hidemichi Katsumata, Japan's Strategy Against Senkaku Island Dispute, JAPAN SECURITY WATCH, (Sept. 14, 2012, 12:20 PM), http://jsw.newpacificinstitute.org/?p=10495 (translated by Kyle Mizokami) (providing a Japanese perspective on this escalation). The U.S. has specifically indicated that its defense commitment reaches the Senkaku/Diaoyu islands as Japanese administered territory. Paul Eckert, Treaty with Japan Covers Islets in China Spat: U.S. Officials, REUTERS, Sept. 21, 2012, http://www.reuters.com/article/2012/09/20/us-china-japan-usa-idUSBRE88J1HJ20120920; PLA Warns US Over Backing Japan in Diaoyus Row, S. ChINA Morning Post, Sept. 13, 2013, http://www.scmp.com/news/china/article/1309056/china-military-tells-us-not-encourage-japan-overisles.

59. China's Maritime Disputes, COUNCIL ON FOREIGN ReL., http://www.cfr.org/asia-andpacific/chinas-maritime-disputes/p31345\#!/?cid=otr-marketing_use-china_sea_InfoGuide (last visited Dec. 30, 2014)

60. Choe Sang-hun, Chinese Fisherman Kills South Korean Coast Guardsman, N.Y. TIMES, Dec.13, 2011, http://www.nytimes.com/2011/12/13/world/asia/chinese-fisherman-kills-south-koreancoast-guardsman.html; Kim Tae-jong, Illegal Chinese fishing boats to face heavier fines, KOREA TIMES, Dec. 4, 2011, http://www.koreatimes.co.kr/www/news/nation/2011/12/117_100109.html.

61. Teddy Ng \& Lawrence Chung, Beijing Visit by Japanese Envoy Gives Chance to Repair Ties, S. CHINA MORNING Post, Feb. 20, 2013, http://www.scmp.com/news/china/article/1154221/beijing- 


\section{B. Framing the Disputes}

While the general fact of China's emergence as a great power may naturally give rise to security concerns among China's neighbors, there can be little doubt that peace would be better served by the elimination of risky disputes over uninhabited islands and their surrounding seas. In regard to the disputes addressed in this article, the cost of a war-like footing or war itself among three developed or rapidly developing nations-China, Japan, and South Korea (along with the U.S.) — would be enormous. The intra-Chinese dispute over Taiwan, while adding further complexity, is set aside here, assuming some shared "Chinese" interests in and mutual assertion of Chinese territorial claims on both sides of the Taiwan Strait. $^{62}$ The three states to be discussed primarily-China, Japan, and South Korea-are all U.N. members and parties to the 1982 UNCLOS. ${ }^{63}$ Contributing to this tense situation has been a tendency of all three states, especially China and Japan, to push claims to base lines and related inland seas, territorial seas, and resource zones that clearly go beyond those contemplated by UNCLOS. Without clearly knowing who first started this cycle of confrontation and excess, the strategy of all appears to be aimed at creating strong bargaining chips as a counterweight to the other side's perceived excess claims. This brew of excess claims and bargaining chips leads to ever-rising escalation of the disputes.

Earlier, in the spirit of Deng Xiaoping's above statement about the wisdom of setting aside such sovereignty disputes and in the shadow of UNCLOS, it was anticipated that temporary joint resource development zones and fisheries could be negotiated while leaving the sensitive claims to uninhabited islands-territorial land claims not being addressed in UNCLOS - for future resolution. This strategy has proven largely fruitless, especially as to the vast oil and gas resources-with

visit-japanese-envoy-gives-chance-repair-ties; Japan-China 'Secret' Talks Held Over Island Row, NATION, Oct. 16, 2013, http://nation.com.pk/international/16-Oct-2013/japan-china-secret-talks-heldover-island-row; No Talks Unless Dispute Affirmed: China, JAPAN Times, Sept. 21, 2013, http://www.japantimes.co.jp/news/2013/09/21/national/no-talks-unless-dispute-affirmed-

china/\#.VHJg7VfF9tI. After a rather belligerent year China seems to be taking up a more conciliatory approach, as has been evident with Vietnam as well. Teddy Ng, China, Vietnam to Set Up Sea Exploration Group, China and Vietnam to Jointly Explore Waters, S. CHINA MoRning Post, Oct. 14, 2013, http://www.scmp.com/news/china/article/1331106/china-vietnam-set-group-explore-disputedsouth-china-sea; Okudera, supra note 46.

62. Taiwan has indeed piped in occasionally to make its concerns known. Lawrence Chung, We Vow Not to Give In Even an Inch, Taiwanese President Ma Tells Japan, S. ChINA Morning Post, Sept. 14, 2012, http://www.scmp.com/news/china/article/1036214/we-vow-not-give-even-inchtaiwanese-president-ma-tells-japan.

63. When China signed and ratified UNCLOS it indicated several exceptions to its acceptance of the treaty, including specifically that nothing in its accession should be construed to conflict in any way with China's territorial law. Query whether this includes its claims within the nine dotted lines to the entire South China Sea and too much of the continental shelf under the East China Sea? UNCLOS does not include island claims. It is important to note that the U.S., though often a participant in these disputes, is not yet a party to UNCLOS, though there has been pressure for U.S. ratification. Mark Landler, Law of the Sea Treaty is Found on Capitol Hill, Again, N.Y. TIMES, May 23, 2012, http://www.nytimes.com/2012/05/24/world/americas/law-of-the-sea-treaty-is-found-on-capitol-hillagain.html. 
only moderate contingent and not fully realized progress in a couple cases. ${ }^{64}$ The reluctance of each party to surrender the leverage of their bargaining chips, which ultimately include uninhabited islands and the surrounding seas, has spawned an impasse. Added to these strategic considerations has been a strong dose of nationalist sentiments on all sides agitating to defend the sovereign territorial claims represented by the islands. ${ }^{65}$ The Chinese government has been especially tolerant (some say encouraging of) public anti-Japanese demonstrations. ${ }^{66}$ Perry Link has noted that this may be a dangerous game for China; if such demonstrations get out of hand they may backfire, turning the public wrath on China itself. ${ }^{67}$

This situation leaves the parties with a strategic log-jam and the question whether any logs can be gently removed from the disputes without collapsing into a state of war. As the level of volatility has increased over time, the urgency of this matter has increased. With some limited fishery exceptions, proposals to ease the risk of conflict and settle the resource disputes have not yet been fruitful. ${ }^{68}$ That failure has led to the effort in this article to turn the process around and consider avenues to addressing the more volatile island disputes first.

Absent the nationalistic passions, the claims to sovereignty over disputed islands by all sides are coherent enough and could be easily resolved on the merits under now-established customary international law through some third-party dispute mechanism. Regarding Senkaku/Diaoyu, the impasse has long been the refusal of both China and Japan to submit the dispute for third-party arbitration or for Japan to even acknowledge there is a dispute to address. In the 2012 speech of

64. Seima Oki, China Vessels Hold Drills Near Gas Fields, Yomiuri Shimbun, Mar. 19, 2012, http://china.timesofnews.com/china-vessels-hold-drill-near-gas-fields/; Japan Protests to China Over Undersea Gas Drilling, Tокуо TiMES (Feb. 2, 2012), http://www.tokyotimes.com/japan-protests-tochina-over-undersea-gas-drilling.

65. Song Wenzhou, Nationalists Pose a Problem for Two Nations, CAIXIN OnLINE (Dec. 6, 2013), http://english.caixin.com/2013-12-06/100614547.html.

66. William Wan, Beijing Both Encourages and Reins in Anti-Japan Protests, Analysts Say, WASH. POST, Sept. 17, 2012, http://www.washingtonpost.com/world/beijing-both-encourages-andreins-in-anti-japan-protests-analysts-say/2012/09/17/dc8c188e-0188-11e2-9367-

4e1bafb958db_story.html?wprss=rss_asia-pacific; Jessica Weiss, Nationalism and Anti-Japan Demonstrations in China, MONKEY CAGE (Sept. 19, 2012), http://themonkeycage.org/blog/2012/09/19/nationalism-and-anti-japan-demonstrations-in-china/.

China's encouragement of nationalistic demonstrations has been evident in China's ability to turn on and off such demonstrations. China Tells Citizens not to hold Anti-Japan Protests, Kyodo NEws, Sept. 19, 2012, http://www.thefreelibrary.com/UPDATE1\%3A+China+tells+citizens+not+to+hold+antiJapan+protests.-a0303222919. Such nationalism has especially been stoked by lingering sentiment about Japan's invasions in World War II.

67. Perry Link, Beijing's Dangerous Game, N.Y. Review of BooKs (Sept. 20, 2012, 11:45 PM), http://www.nybooks.com/blogs/nyrblog/2012/sep/20/beijings-dangerous-game. See also June Teufel Dreyer, The Sino Stranglehold: How Badly Could the Chinese Protests Hurt Japan's Economy?, FOREIGN POL'Y, Sept. 21, 2012, http://www.foreignpolicy.com/articles/2012/09/21/the_sino_stranglehold.

68. Teddy Ng, Japanese Propose Plan to Avoid Maritime Conflicts, Foreign Minister Seeks Endorsements from Wen Jiabao and Wants to Resume Talks on Gas Fields, S. CHINA MoRnING Post, Nov. 24, 2011, http://www.scmp.com/article/985738/japanese-propose-plan-avoid-maritime-conflicts. 
then Japanese Prime Minister Noda before the General Assembly he invoked international law and seemingly signaled a willingness to submit the matter for third-party arbitration, but China's long-standing refusal may have made this no more than a safe ploy. ${ }^{69}$ More recently, Japanese Prime Minister Shinzo Abe's invocation of the rule of law as a basis to address these disputes met with Chinese condemnation. $^{70}$ China has never filed a general submission to the ICJ and has especially resisted application of the ICJ or other third-party dispute mechanisms for resolving disputes over sovereignty in similar circumstances. ${ }^{71}$ Respecting Dokdo/Takeshima, South Korea likewise refuses such third-party dispute

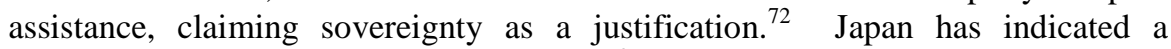
willingness to submit the matter to the ICJ. ${ }^{73}$

Because China, Japan, and South Korea are within 400 nautical miles ("nm") of each other, all claimed resource zones in these enclosed seas overlap and require the parties to negotiate an "equitable solution" as is required under UNCLOS. ${ }^{74}$ The claiming of excessive strait baselines from which to measure the territorial seas by both Japan and China does not contribute to efforts to find such a solution. In 2012, Beijing spurred increased tension by submitting to the U.N. strait baselines for the Diaoyu/Senkaku Islands. ${ }^{75}$ Added to the impasse is the seeming Japanese reluctance to openly accept that it cannot claim the 200nm resource zones under UNCLOS for the uninhabited Senkaku/Diaoyu Islands, a limitation both

69. Japanese Prime Minister Yoshihiko Noda United Nations General Assembly Address, CSPAN (Sept. 26, 2012), available at http://www.c-span.org/video/?308405-4/japanese-prime-ministeryoshihiko-noda-united-nations-general-assembly-address; Time to Put Inferiority Complex Behind Us, GLOBAL Times, Sept. 28, 2012, http://www.globaltimes.cn/content/735883.shtml.

70. Japan, Philiippines Using Rule of Law Pretext: China, XINHUA, June 27, 2014, http://news.xinhuanet.com/english/china/2014-06/27/c_133443927.htm.

71. For example, its refusal of such third party dispute jurisdiction occurred when the Philippines brought a similar dispute over the Scarborough Shoal in the Spratly Islands to the International Tribunal on the Law of the Sea. See, e.g., China Says Philippines Violates International Maritime Law in Claiming South China Shoal, Fox News (Apr. 18, 2012), http://www.foxnews.com/world/2012/04/18/china-claims-philippines-is-violating-maritime-law/;

Samantha Hoffman, Sino-Philippine Tension and Trade Both Rising amid Scarborough Standoff, CHINA BRIEF, vol. 12/9, Apr. 27, 2012, available at http://www.jamestown.org/uploads/media/cb_04_27.pdf; Greg Torode, Manila Action of South China Sea Could Risk Aggravating Disputes, S. ChInA MoRning Post, Jan. 26, 2013, http://www.scmp.com/news/asia/article/1136191/manilas-action-over-south-china-sea-could-riskaggravating-disputes.

72. See generally Pilkyu Kim, Claims to Territory between JaPAN and Korea in INTERNATIONAL LAW (Xlibris, 2014).

73. J. Berkshire Miller, The ICJ and the Dokdo/Takeshima Dispute, DiPlOMAT (May 13, 2014), http://thediplomat.com/2014/05/the-icj-and-the-dokdotakeshima-dispute/.

74. UNCLOS, supra note 6 , arts. 74 and 83.

75. This move was seen as a shift away from the previous policy of setting aside the dispute and negotiating over joint exploration for energy resources and the declaration was accompanied by increased presents of Chinese surveillance ships in the area. Teddy $\mathrm{Ng}$, Beijing Gives UN Baselines for Diaoyu Islands, Spurring Tension with Japan, S. ChINA MoRning Post, Sept. 15, 2012, http://www.scmp.com/news/china/article/1037254/beijing-gives-un-baselines-diaoyu-islands-spurringtension-japan. 
China and Taiwan have acknowledged. ${ }^{76}$ But perhaps the biggest log in the logjam is China's claim to nearly all of the continental shelf between China and Japan as part of what it claims is a natural prolongation of the continental shelf-even though UNCLOS does not appear to allow such option in this situation of opposite states within four hundred nautical miles of each other. ${ }^{77}$ China's similarly excessive claim to nearly all of the South China Sea certainly does not encourage hope that it would readily abandon this excessive claim in favor of a more equitable solution. ${ }^{78}$ Efforts have been made by all sides to negotiate cooperative arrangements in the form of joint resource zones envisioned by UNCLOS but with limited success in implementation. ${ }^{79}$

The pending island disputes have left the parties with too much uncertainty to judge the reasonableness of any proposed resource allocation under UNCLOS guidelines. Before UNCLOS South Korea and Japan were successful at negotiating a joint resource development zone and they have since reached a fisheries agreement. ${ }^{80}$ While China and Japan managed to reach a tentative understanding, they labeled a "principled consensus," in June 2008 calling for joint exploration and possible joint resource development in a 2700 square kilometer area in the East China Sea, it is not clear whether this arrangement will be fully developed and carried out - there being considerable mutual distrust. ${ }^{81}$ Japan and China did reach a joint fisheries agreement covering a large area but excluding the

76. Jon M. Van Dyke, Maritime Boundary Disputes, Settlement Processes, And the LAW OF THE SEA 61-62 (2009).

77. Id. at 58. China has submitted this continental shelf prolongation to the U.N. in a submission entitled "Partial Submission Concerning the Outer Limits of the Continental Shelf beyond 200nm in the East China Sea." China Makes U.N. Appeal for Maritime Claim, UPI, Dec.17, 2012, http://www.upi.com/Top_News/Special/2012/12/17/China-makes-UN-appeal-for-maritime-claim/UPI60871355720880/.

78. South China Sea, Full Unclosure?, ECONOMIST, Mar. 24, 2012, http://www.economist.com/node/21551113/print.

79. Keyuan Zou, Sino-Japanese Joint Fishery Management in the East China Sea, 27 Marine Pol'y 125, 132-40 (2003) (includes the translated agreement as an appendix).

80. Choon-Ho Park, Seabed Boundary Issues in the East China Sea, in Seabed Petroleum in Northeast Asia: Conflict or Cooperation? 18, 18-22 (Selig S. Harrison ed., Woodrow Wilson Int'l. Ctr. for Scholars, 2005), available at http://www.wilsoncenter.org/sites/default/files/Asia_petroleum.pdf. The Japan-Republic of Korea Agreement on Fisheries of 28 November 1998, entered into force on 22 January 1999, as revised on 17 March 1999.

81. Press Release, Ministry of Foreign Affairs of the People's Republic of China, Foreign Ministry Spokesperson Jiang Yu's Remarks on the Principled Consensus Reached between China and Japan on the East China Sea (June 18, 2008), available at http://www.fmprc.gov.cn/mfa_eng/xwfw_665399/s2510_665401/2535_665405/t466675.shtml; Press Release, Ministry of Foreign Affairs of Japan, Joint Press Conference by Minister of Foreign Affairs Masahiko Koumura and Minister of Economy, Trade and Industry Akira Mari (June 18, 2008), available at http://www.mofa.go.jp/announce/fmpress/2008/6/0618.html (regarding Cooperation Between Japan and China in the East China Sea). The tentative nature of the June 18, 2008 "principled consensus" was reflected in even the announcements of the arrangement being made in separate press conferences and the arrangement itself leaving much open for further discussion, though it does provide for cooperation in exploration and some joint investments. 
waters below twenty-seven degrees north near the Senkaku/Diaoyu Islands. ${ }^{82}$ A comprehensive resolution of these problems in the most sensitive areas seems to elude the parties, as they fear surrendering critical bargaining chips, the disputed islands being the most visible. Do current international legal principles offer a way out of these impasses?

\section{INTERNATIONAL LEGAL PRINCIPLES: AN OVERVIEW}

In the context of both sets of island disputes under discussion, the parties are claiming historical title to the islands themselves and claiming rights to maritime resources, including fisheries and oil, and gas deposits in the adjoining seas between the claimant states. ${ }^{83}$ Because the states in question are in close proximity across their adjoining seas and the islands are at intermediate locations, the island disputes have long been contingent factors for resolving the maritime disputes. The discovery of very large oil and gas reserves - some have speculated possibly on the scale of the Middle East or the North Sea - and disputes over the maritime rights that attach to such small islands have created a web of competing claims. ${ }^{84}$ This complex web of claims has often featured the disputed islands and various baseline claims as bargaining chips in the maze of competing resource claims, making resolution of claims that would be relatively easy to resolve in legal terms quite difficult. Elements of nationalism over the island claims have elevated the political sensitivity of these disputes in ways that make political compromise hard to achieve. The challenge has been to unravel these disputes to permit development of sorely needed resources.

In regard to the disputes over these uninhabited islands and the associated maritime boundary and resource claims under present discussion, two rapidly evolving bodies of international law are implicated: territorial claims to uninhabited islands, though not addressed by UNCLOS, are addressed by customary international law; and, the maritime boundary and resource claims, which are addressed rather comprehensively by UNCLOS and associated jurisprudence. These two areas are considered in the following subsections.

\section{A. Customary International Law Relating to Sovereignty over Uninhabited Islands}

Taking up island disputes first, it is a common characteristic of these disputes over remote uninhabited islands in East Asia that a current occupant or claimant vies for sovereignty with other claimants based on assertions of historical title. In the absence of guiding international treaties, this issue has been governed by

82. Zou, supra note 79 , at 133 .

83. See generally VAN DYKE, supra note 76; KIM, supra note 72.

84. While some have worried that the resource claims are exaggerated, they clearly do shape and encourage territorial claims. Cary Huang, Diaoyu Islands Dispute about Resources Not Land, S. China Morning Post, Dec. 4, 2012, http://www.scmp.com/news/china/article/1096774/diaoyu-islands-disputeabout-resources-not-land. See U.S. Energy Info. Admin., East China Sea (2012), available at http://www.eia.gov/countries/analysisbriefs/east_china_sea/east_china_sea.pdf; Roach, supra note 34, at 1-5. 
customary international law. Measuring the viability of competing claims has long involved sifting through remote historical records. As a result, the customary law regarding territorial disputes over uninhabited islands is an area of law peculiarly suited to resolution by the ICJ or international arbitral tribunals, although such referral has proven especially sensitive for Asian states.

A number of guiding customary international law principles regarding territorial claims to uninhabited islands have evolved through case law in recent years. Such claims often implicate issues of historical discovery and effective occupation. In the colonial period, for previously unclaimed islands (belonging to no one, characterized as "terra nullius"), discovery and some formal official act to perfect a claim of sovereignty were generally thought sufficient to establish a claim. ${ }^{85}$ Because the pre-modern Asian international order may have lacked a concept of territorial sovereignty, as this concept is understood today, ${ }^{86}$ further difficulty was added to assessing such historical claims by regimes, which may have lacked a habit to formally assert such claims. This difficulty was made worse by an historical lack of serious interest in such remote islands in the days when they offered fewer accessible resources. ${ }^{87}$

By the mid-twentieth century the colonial era principles that rewarded Western discovery began to fade. Modern international principles that rejected colonialism and embraced modern notions of state sovereignty tended to give little weight to ambiguous claims of historical title based on mere discovery or proximity. ${ }^{88}$ A series of judicial decisions emphasized "effective occupation," which required some acts of administration and control beyond discovery. ${ }^{89}$ In the Pedra Branca case, the ICJ emphasized "effective administration" in awarding the island to Singapore. ${ }^{90}$ Effective administration can involve things such as reclamations, regulation of fishing, construction and maintenance of structures, and the investigation of accidents.

As one commentator emphasized, "active occupation and effective control over territory supersedes ambiguous ancient title." 91 In the Sovereignty Over Pulau Ligiton and Pulau Sipadan case, a dispute between Indonesia and Malaysia over a group of very small islands encompassing just 0.13 square kilometers, the

85. VAN DYKE, supra note 76 , at 47-49, 61.

86. Pilkyu Kim, Reassessment of Korea-Japan Relations: Acquisition of Dokdo/Takeshima and "Effectiveness," Address Before the International Symposium on Dokdo Island (May 7, 2009)in ProceEdings of THE INT'L DoKdo Symposium 2009, at 40-44; Tao Cheng, The Sino-Japanese Dispute Over the Tiao-yu-tai (Senkaku) Islands and the Law of Territorial Acquisition, 14 Va. J. Int'1 L. 221, 242-43 (1973-1974).

87. Cheng, supra note 86 , at 246

88. VAN DYKE, supra note 76 , at $47-49,61$.

89. See Minquiers and Ecrehos (Fr./U.K.), Judgment, 1953 I.C.J. 47 (Nov. 17); Sovereignty Over Clipperton Island (Fr. v. Mex.) (1931), reprinted in 26 AM. J. INT'L L. 390 (1932); Island of Palmas (U.S. v. Neth.), 11 R.I.A.A. 831 (Perm. Ct. Arb. 1925).

90. Sovereignty Over Pedra Branca/Pulau BatuPuteh, Middle Rocks and South Ledge (Malay./Sing.), Judgment, 2008 I.C.J. 12, III 170-72 (May 23).

91. Alexander M. Peterson, Sino-Japanese Cooperation in the East China Sea: A Lasting Arrangement? 42 Cornell Int'1 L.J. 441, 451 (2009). 
ICJ held that mere discovery was not enough, that "effective occupation," including displays of sovereignty and administration were essential to prove ownership. ${ }^{92}$ The ICJ further held that failure to protest another state's occupation is de facto acceptance. ${ }^{93}$ The Court found effective occupation based on a "continued display of authority [that] involves two elements each of which must be shown to exist: the intention and will to act as sovereign, and some actual exercise or display of such authority." 94

As Greg Austin summarizes it, "[i]nternational customary law recognizes acquisition of title to territory belonging to no-one (terra nullius) through discovery, but this title remains inchoate and must be converted to a more complete title through continued, peaceful and unprotested exercise of sovereignty." 95 Merely showing that some private nationals of the claiming state, such as fishermen, visited the islands from time to time would be insufficient. ${ }^{96}$ Austin notes that you can weigh the relative strength of competing historical claims through analysis of historical, geographical, and administrative circumstances. 97 Case law also emphasizes a "critical date," such that acts affected after the joining of a dispute cannot have a bearing on the sovereignty claim. ${ }^{98}$ This "critical date" aspect, for example, would limit China's ability to perfect its claims to contested islands in the South China Sea by building platforms or other occupation activities.

Scholars and officials in East Asia often raise an irredentist problem, questioning whether the heightened standards of "effective occupation" should be applied to claims that arose in an earlier historical period before the West arrived on the Asian scene. ${ }^{99}$ Such critics favor the application of standards contemporary to the time the claim arose. ${ }^{100}$ But this argument raises a policy problem for current tribunals about whether to give effect to either colonialist or imperialist standards that applied at the time of alleged ancient discovery. The better view appears to require that some standards of effective occupation be applied even to claims originating in ancient times. Ancient claims also face a problem of proof

92. Sovereignty Over Pulau Ligiton and Pulau Sipadan (Indon./Malay.), Judgment, 2002 I.C.J. 625 (Dec. 17).

93. Id. II 148 .

94. Id. था 134

95. Greg Austin, China's Ocean Frontier, International Law, Military Force and NATIONAL DEVELOPMENT 36 (Canberra: Allen \& Unwin, 1998). In this context terra nullius generally refers to territory not ruled by a recognized state, which could be the consequence of no previous discovery and claim or abandonment of a previous claim.

96. Pulau Sipadan, 2002 I.C.J. II 140.

97. Austin, supra note 95, at 36-40.

98. Id. at 40. Austin notes that in the Island of Palmas Case the critical date was not when the dispute arose but when it became "crystallized," when the parties "are no longer negotiating or protesting, or attempting to persuade one another." Rather, they have taken up positions and are standing on their respective rights. Id.

99. Tao Cheng, supra note 86 , at 2642-43.

100. $I d$. 
that a modern tribunal may be reluctant to address. Claims to the uninhabited islands addressed herein face nearly all of these challenges.

\section{B. Maritime Resource Boundaries under UNCLOS}

Though UNCLOS does not address the island sovereignty claims, it is highly relevant in regard to the related maritime resource boundary disputes. UNCLOS governs the allowance of territorial seas and other resource zones associated with all coastal areas, including islands. ${ }^{101}$ With research showing major oil and gas reserves, as well as rich fishery zones, at or near both sets of islands, UNCLOS and its various authoritative interpretations offer very useful guidance toward resolving these testy disputes. ${ }^{102}$ UNCLOS allows states to claim four designated maritime zones relevant to the present disputes: the inland sea, the territorial sea, the EEZ, and the continental shelf. ${ }^{103}$ Air Defense Identification Zones, as has recently been proclaimed by China, are not covered by UNCLOS or other maritime treaties. ${ }^{104}$ The area beyond these four zones is the high seas, where navigational freedom of seas prevails and seabed resources are treated as part of the common heritage of mankind. ${ }^{105}$

Where various baselines and boundaries are drawn, in the East China Sea and the Sea of Japan, will have large implications for the major associated resource claims involved in the disputes under consideration here. The rights to the disputed islands and the associated resource rights will likewise implicate the resource boundaries that emanate outward from base lines. The widely varied consequences, in respect to various possible outcomes of the island sovereignty disputes, explains the difficulty of reaching provisional cooperative arrangements with regard to the maritime resource disputes: as disputants are reluctant to embrace a tentative agreement that appears to presume a particular territorial outcome.

Under UNCLOS, baselines are generally drawn at the low tide mark on land and strait baselines are allowed where the coast is "deeply indented" or has a "fringe of islands." 106 Coastal areas may include islands as base points in a straitbaseline delineation only where the resulting baselines do "not depart to any

101. See generally UNCLOS, supra note 6 .

102. See VAN DyKe, supra note 76; Austin, supra note 95. While all three disputants in the present discussion have signed and ratified UNCLOS, the U.S. has only signed but not ratified the treaty, though the U.S. long ago proclaimed it adhered to all of its provisions except those respecting deep sea bed minerals and their management. The matter was recently again before the U.S. Senate to consider ratification, which key Republicans have long opposed. See Mark Landler, Law of the Sea Treaty Is Found on Capitol Hill, Again, N.Y. Times, May 23, 2012, http://www.nytimes.com/2012/05/24/world/americas/law-of-the-sea-treaty-is-found-on-capitol-hillagain.html?_r=0. The U.S. lack of ratification no doubt weakens its leverage in pushing others to settlement of disputes under its terms.

103. UNCLOS, supra note 6 , arts. 2, 8, 55-56, 76, 86-87.

104. Peter A. Dutton, Caelum Liberum: Air Defense Identification Zones Outside Sovereign Airspace 103 Am. J. Int'1 L. 691, 694 (2009).

105. UNCLOS, supra note 6, arts. 86-87.

106. Id. art. 7(1) 


\section{INT'L LAW \& THE UNINHABITED ISLANDS IN THE EAST CHINA SEA}

appreciable extent from the general direction of the coast." 107 Archipelagic states, which for Japan include the Ryukyu Islands archipelago to the south of Japan encompassing most of the area opposite to China, are allowed to draw strait baselines "joining the outermost points of outermost islands." 108

Under UNCLOS, internal waters include those sea areas inland from baselines and the territorial sea and other zones emanate outward from the base line. ${ }^{109}$ UNCLOS allows up to $12 \mathrm{~nm}$ for territorial seas. ${ }^{110}$ This applies both to islands and continental coasts and is fully under the sovereignty of the coastal state. ${ }^{111}$ States are also allowed to claim up to 200nm of EEZ from the same baselines, where such states have exclusive rights in fisheries and other natural resources. ${ }^{112}$ The 200nm EEZ is likewise provided in relation to both continental and island coasts. ${ }^{113}$ A continental shelf of up to $200 \mathrm{~nm}$ and, in some cases where the natural prolongation extends further, up to $350 \mathrm{~nm}$, is allowed. ${ }^{114}$ Under this provision, all states, regardless of the contours of their continental slope, are entitled to at least a $200 \mathrm{~nm}$ continental shelf, with an exception for opposite or adjoining states with less than $400 \mathrm{~nm}$ between them. ${ }^{115}$

For opposite or adjoining states with potentially overlapping resource jurisdiction, UNCLOS requires parties to reach an agreement "on the basis of international law in order to reach an equitable solution" in delimiting resource zone boundaries. ${ }^{116}$ While the 1969 North Sea Continental Shelf case spoke of natural prolongation, ${ }^{117}$ the adoption of UNCLOS Articles 74(1) and 83(1) suggest an agreement on "equitable" boundaries; in tandem with Article 76(1), this has brought about the effective demise of this notion for opposite states within $400 \mathrm{~nm}$ of each other. ${ }^{118}$ The ICJ made this clear in the 1985 Libya $v$. Malta case, stating:

Since the development of the law enables a State to claim that the continental shelf appertaining to it extends up to as far as 200 miles from its coast, whatever the geological characteristics of the corresponding sea-bed and subsoil, there is no reason to ascribe any role to geological or geophysical factors within that distance either in verifying the legal title of the states concerned or in proceeding to a delimitation as between their claims. ${ }^{119}$

107. Id. art. 7(3).

108. Id. art. 47(1)

109. Id. art. 8 .

110. Id. art. 3.

111. Id. arts. 2, 4-5.

112. Id. art. 57. Islands are entitled to a territorial sea, an EEZ, and a continental shelf "in accordance with the provisions . . applicable to other land territory." Id. art. 121(2).

113. Id. arts. $57,60-61,74$.

114. $I d$. art. 76 .

115. Id. arts. $76(1), 74$.

116. $I d$. arts. 74,83 .

117. North Sea Continental Shelf Case (Ger. v. Den./Neth.), 1969 I.C.J. 3 (Feb. 20).

118. VAN DYKE, supra note 76, at 58.

119. Continental Shelf (Libya v. Malta), 1985 I.C.J. 13, If 39 (June 3). The case involved a similar situation to China and Japan, with a continental state (Libya) and an opposite offshore island state 
An equitable solution also appears to take account of proportionality in regard to the relative length of the opposing coastlines. Jon Van Dyke points out that, while the starting point seems to be equidistant or median lines, tribunals will make adjustments, as they did in the Libya $v$. Malta case, to bring the ratio of the relative length of coastlines more into line with the maritime space allocated. ${ }^{120}$

Of particular relevance to the present discussion of uninhabited islands, UNCLOS Article 121(3) provides, "[r] ocks which cannot sustain human habitation or economic life of their own shall have no exclusive economic zone or continental shelf," though such islands are entitled to a territorial sea. ${ }^{121}$ A precise definition of what would be a mere rock is not afforded, though both island groups under present discussion potentially fall under this provision. ${ }^{122}$ Is an island that has grass and trees growing on it but has never been used for normal human habitation a mere rock under this provision? There is certainly a policy argument that such designation would greatly reduce associated disputes.

With little agreement over rights to either the uninhabited islands or the boundaries of the maritime resource zones at issue, the earlier decision of all parties to set aside the island territorial disputes and work on cooperative use of resources under UNCLOS seemed practical. UNCLOS encourages "provisional cooperative arrangements." "123 With continuing disagreement over such islands and only limited often-unrealizable cooperation concerning resource areas, especially between China and its potential partners, this approach has proven a failure. These island disputes, along with disagreement over baselines and respective rights in the continental shelf, have given rise to the current impasse and related security concerns. That uninhabited islands are involved, and not merely

(Malta). A state not facing an opposite state within 400nm can sometimes justify an extended continental shelf based on natural prolongation or appurtenant to islands, as was recognized by the U.N. Commission on the Limits of the Continental Shelf with respect to Japanese claims to uncontested areas in April 2012. See UN Approves Japan's Claim on Wider Areas, YomIURI SHIMBUN, Apr. 29, 2012, http://news.asiaone.com/News/AsiaOne+News/Asia/Story/A1Story20120429-342721.html (netting Japan 310,000 square kilometers).

120. Continental Shelf, 1985 I.C.J. III 11, 64-65; VAN DYKE, supra note 77, at 59. See also Gulf of Maine Area (U.S. v. Can.), 1984 I.C.J. 246 (Oct. 12); Case Concerning Maritime Delimitation in the Area between Greenland and Jan Mayen (Den. v. Nor.), 1993 I.C.J. 38 (June 14); Delimitation and Territorial Questions between Qatar and Bahrain (Qatar v. Bahr.), 2001 I.C.J. 40, at 111 (Mar. 16). See also Dispute Concerning Delimitation of the Maritime Boundary between Bangladesh and Myanmar in the Bay of Bengal (Bangl. v. Myan.), Case No. 16, Judgment of Mar. 14, 2012, ITLOS Rep. 1, II 319, available at http://www.itlos.org/fileadmin/itlos/documents/cases/case_no_16/1C16_Judgment_14_02_2012.pdf (reflecting that St. Martin's Island got no EEZ based on such adjustment in competition with an opposite continental land, even though the island was substantial with 3,700 permanent residents).

121. UNCLOS, supra note 6, art. 121(3).

122. Sourabh Gupta has pointed out that some very small uninhabited islands have been the subject of valid or pending claims for an EEZ and a continental shelf, including Japan's low-lying Okinotorishima, the very small U.S. Howland and Baker Islands, and Australia's remote Heard and McDonald Islands. Sourabh Gupta, Murky Waters Surround the Rule of Law in the South China Sea, East Asia Forum (July 20, 2014), http://www.eastasiaforum.org/2014/07/20/murky-waters-surroundthe-rule-of-law-in-the-south-china-sea/.

123. UNCLOS, supra note 6 , arts. 74, 83. 
maritime resource claims, has also encouraged nationalist passions that give priority to sovereignty claims and make legal settlements difficult. Compromise, even in areas where the law seems clear, has eluded the parties, as they fear surrendering any claim that may possibly serve as a bargaining chip in dealing with other issues. An assessment of Dokdo/Takeshima and Senkaku/Diaoyu respectively in the next two sections is followed in the third section below by an assessment of the parties' related resource boundary claims and agreements.

\section{SOVEREIGNTY OVER THE DOKDO/TAKESHIMA ISLANDS}

The competing South Korean and Japanese legal claims to the Dokdo/Takeshima Islands share much in common with the Senkaku/Diaoyu Islands dispute and the disputes over other uninhabited islands in the South China Sea, even while the historical narrative and present-day tangle of claims for each set of islands remain distinct. As such, any third-party dispute resolution process that may be agreed offers tremendous opportunity to establish local legal precedent in East Asia that may be helpful in resolving other similar disputes, especially relating to the sufficiency of ancient discovery, the more common-place historical indicia of effective occupation, and the associated maritime resource boundary claims.

Dokdo/Takeshima is located in the Sea of Japan (what South Korea calls the East Sea) and consists of two very small rocky islands and approximately thirtytwo smaller outcroppings with a total area of only 0.18 square kilometers, approximately $47 \mathrm{~nm}$ from South Korea's occupied and inhabited Island of Ullungdo and 86nm from Japan's occupied and inhabited Oki Island. ${ }^{124}$ The islands are currently, and have for decades been, occupied by South Korea. ${ }^{125}$

While the dominant view in case law and the literature has generally been favorable to the South Korean territorial claim to the Dokdo/Takeshima Islands, submitting the island dispute to the ICJ or another arbitration process, as was long ago offered by Japan, ${ }^{126}$ may be more useful to Japan than simply reaching a negotiated settlement. A definitive answer on the merits can only be offered by a tribunal with proper jurisdiction. ${ }^{127}$ Such a tribunal can help to establish important legal principles. Such a process would allow the parties to test the water on various legal issues that surround this and other similar East Asian island disputes. Such test could facilitate gentle removal of a log from the above-noted log-jam.

As with many uninhabited islands, the historical record to measure the required "effective occupation" of Dokdo/Takashima is thin. In the face of such thinness, South Korea, the current occupant of several decades standing would

124. VAN DYKE, supra note 76 , at 46.

125. The Korean Government's Basic Position on Dokdo, Ministry of Foreign Aff. Republic of Korea, http://dokdo.mofa.go.kr/eng/dokdo/government_position.jsp (last visited Nov. 24, 2014).

126. Miller, supra note 73.

127. The concern is to submit the matter to a tribunal with proper jurisdiction which, for the ICJ, would require consent to jurisdiction either in the case or generally to compulsory jurisdiction. See Statute of the International Court of Justice art. 36, June 26, 1945, 59 Stat. 1055, 1060 [hereinafter ICJ Statute]. 
certainly enjoy an advantage. Japan bases its claim to the Dokdo/Takeshima Islands on the theory that the islands were terra nullius on February 22, 1905, when Japan first claimed them-under Korean protest - by occupation through a cabinet decision and proclamation by the Governor of Japan's Shimane Prefecture. ${ }^{128}$ After such proclamation, on June 5, 1906, the Japanese government formally issued a fishing license to one Yozaburo Nakai. ${ }^{129}$ Before 1905, Japan could only claim connection through the private acts of Japanese fisherman, with official Japanese permission, visiting the islands as early as 1618; this largely ended in 1696 when Ulleungdo (not specifically Dokdo, which was merely a stopover on the way) was acknowledged by the Japanese Shogunate as under Korean sovereignty, resulting in Japanese being denied permission from their government to visit the area of either set of islands. ${ }^{130}$ Japan does raise the issue of Korean "withdrawal" from the islands from the 15 th to the 19th centuries, during the period when the region was dominated by the Mongol empire, but South Korea highlights a substantial level of visits and contacts during this period and its official re-colonization policy from 1881 to justify the maintenance of its claims and a lack of abandonment. ${ }^{131}$

South Korea claims title to Dokdo based on ancient discovery in 512 followed up by claimed "effective occupation" in the years since. ${ }^{132}$ The Korean position is further bolstered by the claim that Japan was bound to surrender the islands to Korea at the end of World War II, both under Japan's 1945 Instrument of Surrender and the 1951 San Francisco Peace Treaty. ${ }^{133}$ The relative proximity of the islands to Korean territory and South Korea's current occupation since asserting its claim in 1952 and building a guarded lighthouse in 1954-even though protested by Japan every year-would seem to further bolster the Korean claim in any close case. ${ }^{134}$ Though the Korean historical title claims are thin, as is common for remote uninhabited islands, they appear more substantial than Japan's claims.

As discussed by the late Professor Pilkyu Kim, South Korea cites a number of classical Korean texts, such as the Chronicles of the Three Kingdoms, to support the following chronology in support of the Korean case: first, the islands were first discovered - creating an inchoate title-along with Ulleungdo in 512 by the Silla Kingdom, as inferred from the Chronicles of the Three Kingdoms; ${ }^{135}$ second, disputes over the islands relating to fisheries were reportedly settled with Japan

128. Pilkyu Kim, supra note 86 , at 39-98, 40-44.

129. Id.

130. Id.

131. Id. at 58-60.

132. Id. at $45-50$.

133. Treaty of Peace with Japan art. 2, Sept. 8, 1951, 3 U.S.T. 3169, 136 U.N.T.S. 45 . Korea was not a party to the 1951 peace treaty.

134. While any occupation after the critical date that the dispute arises would presumably have no effect on the underlying claims, it would seem to at least establish continued occupation and nonabandonment to the present. See Peterson, supra note 91; AUSTIN, supra note 95, at 40.

135. Pilkyu Kim, supra note 86 , at 45-50. 
recognizing Korea's sovereign rights in $1696 ;{ }^{136}$ third, two prosecutions, one by the Royal Court of Korea in 1716 and one by Japan (for smuggling from Japan to a foreign island (Dokdo)) in 1837 tend to demonstrate a shared belief in Korean sovereignty; ${ }^{137}$ fourth, a number of edicts relating to the islands in the late 19th century in the lead up to the Japanese occupation demonstrate continued Korean occupation; ${ }^{138}$ fifth, South Korean seizure of the islands in 1954 further indicates such claim; ${ }^{139}$ and sixth, continuing South Korean control-over Japanese protest-sustains that claim up to the present. ${ }^{140}$ Kim notes that Japan never protested Korean actions until 1905-perhaps the critical date. ${ }^{141}$ He notes that a number of Korean official maps over the centuries, which have shown Dokdo as Korean territory, have not been challenged. ${ }^{142}$

This dispute has been made more difficult by the failure of World War II and post-war declarations and treaties to resolve the issue or specifically mention these remote islands. In particular, the San Francisco Peace Treaty between Japan and most allied powers, for which Korea was merely a beneficiary but not a party, ${ }^{143}$ failed to expressly include the Dokdo/Takeshima Islands among the listed territories to be surrendered by Japan. ${ }^{144}$ South Korea emphasizes that it should have been included because the San Francisco Peace Treaty incorporated the Cairo Declaration of 1943, which called for the forfeiture of all Japanese territory taken "by violence or greed." 145 Likewise, the 1945 Potsdam Declaration stated that, "[t]he Terms of the Cairo Declaration shall be carried out and the Japanese sovereignty shall be limited to the islands of Honshu, Hokkaido, Kyushu, Shikoku and other minor islands as we determine." 146

Not being a party to the San Francisco Peace Treaty, South Korea claims it recovered its territory by virtue of the September 2, 1945 Instrument of Surrender, by which Japan agreed to both declarations, resulting in the establishment of the Republic of Korea on August 15, 1945 and its recognition by the U.N. on December 8, 1948. ${ }^{147}$ While the failure of the San Francisco Peace Treaty to specifically mention the islands leaves some ambiguity, it would seem that the

136. Id.

137. $I d$.

138. Id.

139. $I d$.

140. Id.

141. Id. at $49,75-76$

142. Id. The author mentions that even a couple Japanese maps have excluded Dokdo/Takeshima Island from Japanese territory.

143. Minoru Yanagihashi, The Territorial Questions in East Asia and San Francisco Peace Treaty: Historical Perspective, Paper Presented at the 2011 Annual Meeting of the Association of Asian Studies in Honolulu, Hawaii (Apr. 2011).

144. $I d$.

145. Press Release, U.S. State Dep't, Cairo Declaration (Dec. 3, 1943), available at http://www.ndl.go.jp/constitution/e/shiryo/01/002_46/002_46_0011.html.

146. Potsdam Declaration: Proclamation Defining Terms for Japanese Surrender (July 26, 1945), in 2 Ministry of Foreign AFF.: NiHON GAIKo NeNPYo NARABINI SHUYo BUnSHO: 1840-1945 (1966), available at http://www.ndl.go.jp/constitution/e/etc/c06.html.

147. Pilkyu Kim, supra note 86, at 69-71. 
connection of the Japanese claim to its expansionist policies in 1905, including the conquest of Korea, favor the South Korean claim. South Korea's subsequent acts to seize back the islands from 1952-1954, soon after World War II and its own Korean War, would further argue in South Korea's favor. ${ }^{148}$

An important related issue, further discussed below, is the likelihood that South Korea would not attempt to claim any resource zones under UNCLOS, beyond the territorial sea, thus, making Dokdo/Takeshima irrelevant to delineating resource zone boundaries. ${ }^{149}$ Jon Van Dyke notes the near futility of either party claiming resource zones for these barren rocks, though the Japanese have been reluctant to explicitly so state out of fear this may affect other island claims Japan seeks to maintain. ${ }^{150}$ South Korea may be less constrained and may move forward to address related resource boundary issues if it acknowledges that Dokdo/Takeshima will not have an impact on median boundary lines. These "rocks" clearly cannot independently sustain life and such limitation would be the likely outcome of any dispute resolution process before the ICJ or otherwise. With greater proximity to South Korea, the islands would be on the South Korean side of any equidistant or median line that may someday be realistically adopted to delineate resource zone boundaries between the South Korean Island of Ullongdo and the Japanese Island of Oki.

With much less nationalism at play on the Japanese side for this particular island dispute (in comparison to the Senkaku/Diaoyu dispute discussed below), there appears little incentive for Japan to insist on its claim to the island if any advantage may be achieved by conceding to a dispute resolution process. Indeed, Japan first proposed submission of the matter to the ICJ in 1954 and again in 1962. ${ }^{151}$ Rather than surrender its claim, Japan would seemingly be more interested in engaging a process that may set a favorable precedent in regard to its other island and maritime disputes. For South Korea, nationalistic sentiments are much more deeply felt in relation to these islands and have seemingly stood in the way of its willingness to embrace such ICJ resolution. South Korea has argued that this is a matter of sovereignty and should not be subject to ICJ resolution as a mere territorial dispute. ${ }^{152}$ Any distinction between territory and sovereignty appears weak and has never been a reason for declining ICJ assistance. ${ }^{153}$ Most territorial disputes involve sovereignty.

The natural resource claims at stake in the surrounding sea areas, as discussed below, have lent a degree of urgency to this and other related disputes. This will

148. Id.

149. See Jon M. Van Dyke, Addressing and Resolving the Dokdo Matter, in PROCEEDINGS OF THE INT'L DOKDO SYMPOSIUM, supra note 86 , at 137-58.

150. Id. at 152-53.

151. Ralf Emmers, Japan-Korea Relations and the Tokdo/Takashima Dispute: The Interplay of Nationalism and Natural Resources 12 (S. Rajaratnam Sch. of Int'l Studies Sing. (RSIS), Working Paper No. 212, 2010).

152. Id.

153. Brian Taylor Sumner, Note, Territorial Disputes at the International Court of Justice, 53 DUKE L.J. 1779, 1779 (2004). See also Island of Palmas, supra note 89, at 8. 
hopefully encourage further consideration of the merits of a dispute resolution process that may bring clarity to the respective rights of the claimants and enable private companies from both sides and around the world to move forward on extraction of resources increasingly needed in the region. The post-war political climate appeared to be improving until the past couple years, as China's failure to address South Korean concerns in respect to military confrontations with North Korea and increasingly tense Sino-Japanese relations had brought South Korea and Japan much closer in their existing security alliance, despite continuing tensions over Japan's World War II legacy. ${ }^{154}$

The past couple years has seen a shift back toward greater hostility on which China has sought to capitalize. Of concern to Japan's shared primary security partner, the U.S., nationalistic sentiment on both sides threatens to undermine their historical security arrangement. On the South Korean side, such nationalism was on display in August 2012 when then President Lee Myung-bak made the first ever presidential visit to the Dokdo Islands and again when South Korea formally renamed peaks on the islands. ${ }^{155}$ The recent emergence of a more nationalistic Japanese leadership under the Liberal Democratic Party has squandered a great deal of good will in the past year, as Korean wounds from World War II have been exposed. ${ }^{156}$ One would hope this situation is salvageable and level heads will prevail.

\section{SOVEREIGNTY OVER THE SENKAKU/DIAOYU ISLANDS}

The Senkaku/Diaoyu Island claims pose a greater challenge than the Dokdo/Takeshima dispute discussed above, with high levels of nationalism at play on both sides in Japan and China, and an even more contentious relationship between the parties. ${ }^{157}$ Despite efforts to avoid confrontation over this issue a number of disputes arose over recent years before things heated up to the tense

154. Both South Korea and Japan have had shared security arrangements with the United States since the end of the Korean War and World War II, respectively, and both host U.S. military bases, producing a need for cooperation. See Sang-hun Choe, South Korea to Sign Military Pact with Japan, N.Y. TIMES, June 28, 2012, http://www.nytimes.com/2012/06/29/world/asia/south-korea-to-signhistoric-military-pact-with-japan.html?_r=0.

155. South Korea Renames Disputed Islands, ABC News (Oct. 28, 2012, 12:57 AM), http://www.abc.net.au/news/2012-10-28/an-sth-korea-renames-disputed-islands/4338020.

156. South Korean President Unimpressed by Japanese PM's Attempt to Speak Korean, S. CHINA MORNING POST, Mar. 26, 2014, http://www.scmp.com/news/asia/article/1457844/seoul-unmovedjapan-hails-bridge-building-summit?page=all; Alastair Gale, How Bad Will South Korea-Japan Relations Get?, WALL ST. J., June 24, 2014, http://blogs.wsj.com/korearealtime/2014/06/24/how-badwill-south-korea-japan-relations-get/.

157. See Chien-Peng Chung, Domestic Politics International Bargaining and China's TERRITORIAL Disputes, ch. 3 (Routledge 2004) (dealing with the nationalist politics behind the Senkaku/Diaoyu dispute). As China has developed and gained greater power over the past decade there has appeared a heightened sense of Chinese nationalism over these island disputes. See Erica Strecker Downs \& Phillip C. Saunders, Legitimacy and the Limits of Nationalism: China and the Diaoyu Islands, in THE RISE OF CHINA 41, 42-43, 73 (Michael E. Brown et al. eds., 2000). 
situation that prevails today. ${ }^{158}$ Recent efforts to even sit down and discuss this dispute have been fraught with obstacles from nationalistic sovereignty claims. ${ }^{159}$ As with Dokdo/Takeshima, the vast store of natural resources of gas and oil thought to be in the area, not to mention fisheries, lends great urgency to resolving the disputes. While the former Japanese Foreign Minister Koichiro Genba appeared to signal, in a commentary in the International Herald Tribune, that Japan might accept the jurisdiction of the ICJ, to which Japan has acceded generally, China has long refused to accept ICJ dispute resolution. ${ }^{160}$ Genba emphasized that since Japan now holds the islands and has accepted the compulsory jurisdiction of the ICJ it would be open to China to bring its challenge before the court. ${ }^{161}$ Professor Jerome Cohen has argued that such a route would offer several advantages to both sides, including a cooling off period and, during the long years when the matter was before the court, a context in which a settlement would be encouraged. ${ }^{162}$

Short of such an optimal path, there is wiggle room to diminish if not resolve this island dispute in several respects: first, as discussed above, a number of ICJ and other decisions in recent years have clarified the law, pointing to the likely outcome of an international legal decision on the merits; ${ }^{163}$ second, progress suggested above for resolving the Dokdo/Takeshima dispute may offer even greater clarity on the international legal standards applicable to the

158. Han-yi Shaw offers an overview of the past developments and the respective claims to the islands and discusses crises that arose in 1970, 1978, 1990, and 1996. Han-yi Shaw, The Diaoyutai/Senkaku Islands Dispute: Its History and an Analysis of the Ownership Claims of the P.R.C., R.O.C., and Japan 13-21 (Univ. of Md., Occasional Papers/Reprint Series, No. 3 (152), 1999).

159. Early 2013 proposals for discussions made to China's new leaders by the new leadership in Japan were met with an improved tone but also with caution. Nothing ever materialized. Teddy $\mathrm{Ng}, X i$ Jinping to Consider Summit with Japan over Diaoyu, S. China Morning Post, Jan. 26, 2013, http://www.scmp.com/news/china/article/1136327/xi-jinping-consider-summit-japan-over-diaoyuislands; Jane Perlez, Chinese Leader Takes Conciliatory Tone in Meeting with Japanese Lawmaker, N.Y. TIMES, Jan. 25, 2013, http://www.nytimes.com/2013/01/26/world/asia/chinese-leader-eases-tonein-meeting-with-japan-envoy.html.

160. Koichiro Genba, Japan-China Relations at a Crossroads, N.Y. Times, Nov. 20, 2012, http://www.nytimes.com/2012/11/21/opinion/koichiro-genba-japan-china-relations-at-acrossroads.html?_r=0.

161. Id. China has so far not met that challenge. While Beijing has never agreed to ICJ jurisdiction generally or specifically over such matters, there has been some speculation that its September 2012 attempt to assert sea boundary base lines to the disputed Diaoyu/Senkaku islands may signal efforts to lay the foundation for such litigation. Teddy Ng, Beijing may seek Legal Solution to Diaoyus Row with Japan, Analysts say, S. ChINA MoRning Post (Sept. 15, 2012, 12:00 AM). It should be further noted that when Japan acceded to the ICJ in 1958 it attached two reservations: (1) that any compulsory jurisdiction was subject to the other disputant having accepted compulsory jurisdiction and (2) that the subject under dispute be limited to situations or facts after 1958. Han-yi Shaw, supra note 158, at 128. Even if China accepted compulsory jurisdiction the second reservation would be sufficient for Japan to avoid jurisdiction in this case if desired. An effort to agree on such would seemingly have to be initiated by the PRC.

162. Jerome Cohen, How Dangerous Are Sino-Japanese Tensions?, ChINA FILE (Aug. 1, 2013), http://www.chinafile.com/how-dangerous-are-sino-japanese-tensions.

163. See supra Part IIIA. 
Senkaku/Diaoyu dispute; third, China's rapid development and insatiable resource needs have brought more urgency to the matter, as has Japan's almost total reliance on imported energy, now increased as a result of diminished use of nuclear power; and, fourth, any future Japanese willingness to agree with the position already taken by the People's Republic of China ("PRC") and Taiwan that the Senkaku/Diaoyu Islands, as "rocks" under UNCLOS Article 121(3), are entitled only to a twelve mile territorial sea and not any resource zones-continental shelf or EEZ - would surely go a long way to reducing the importance of the dispute.

In regard to the latter point, as will be discussed in the next section below, any Chinese willingness to revise its own baselines vis a vis off-shore islands may facilitate such a Japanese move-as these various claims are likely viewed as bargaining chips in the overall dispute. By the same token, any Chinese perception that settlements in the East China Sea may positively impact its position in the South China Sea may encourage a more responsible effort to abandon some of its more extreme claims in favor of compromise.

On the merits, customary international law regarding such uninhabited island claims offers good potential to resolve the sovereignty part of the Senkaku/Diaoyu dispute. It seems likely, based on the various ICJ decisions noted above, ${ }^{164}$ that the outcome would favor Japan, though this is not certain and only a proper tribunal could give a definitive answer. The historical title record is much thinner than that evident for Dokdo/Takeshima. As with Dokdo/Takeshima, the Japanese occupation and formal claim to the islands date to the turn of the 20th century and is based on occupation after its determination that the islands were then terra nullius. ${ }^{165}$ Japan claims to have acquired title following a series of surveys between 1885 and 1895 during which the Japanese deemed there were no signs of Chinese control; they formally took control by a cabinet decision issued on January 14,1895 , by which they incorporated the islands into Japanese territory months before Taiwan was conceded under the Treaty of Shimonoseki. ${ }^{166}$ This was followed by the granting of concessions to and patrolling of the islands from that date forward. ${ }^{167}$

Japan takes the view that either China had no historical title for lack of effective occupation or that any claim they had was abandoned. ${ }^{168}$ A recent Japanese media report has turned up a 1950 document from the Chinese Foreign Ministry archive that acknowledged the island as Japanese territory, a document Japan alleges has spawned closure of relevant parts of the archive for vetting. ${ }^{169}$

164. See supra Part IIIA

165. AUSTIN, supra note 95, at 113.

166. Id.

167. Id.

168. Situation of the Senkaku Islands, JAPAN MINISTRY OF FOREIGN AFF. (Apr. 4, 2014), http://www.mofa.go.jp/a_o/c_m1/senkaku/page1we_000010.html.

169. Julian Ryall, Beijing Cuts Access to Documents 'that Support Japan's Claim to Diaoyus', S. China Morning Post, Feb. 2, 2013, http://www.scmp.com/news/china/article/1141425/beijing-cutsaccess-documents-support-japans-claim-diaoyus; Curtailed Access to China's Diplomatic Archives Fuels Senkaku Conjecture, JAPAN TIMES, Feb. 1, 2013, 
Japan notes further that a 1953 article in the official People's Daily, five years after the founding of the PRC, described the Ryukyu Islands (Okinawa) as including the Senkaku Islands, which they feel concedes a lack of Chinese claim. ${ }^{170}$

The PRC position is that these islands are historical Chinese territory dating at least from the Ming Dynasty (1368-1644) when they were a navigational point in the coastal defense system of China and instrumental in its historical tributary relationship with the ancient Ryukyu kingdom in present day Okinawa. ${ }^{171}$ Their claim is essentially based on discovery plus effective occupation. But only two acts of actual Chinese occupation before 1895 are cited by various sources: the islands' use in the 16th century as a navigational point in the coastal defense system and a one-off grant of ownership to a private party by Chinese imperial edict in $1893 .{ }^{172}$ Austin argues that inclusion in a coastal defense system to contain piracy proves nothing since even high sea locations can be used for this navigational purpose; while he accepts that a grant of ownership is an official act, he doubts that this seeming one-off arrangement is sufficient to prove effective occupation. $^{173}$ A Japanese researcher has also cited a Ming Dynasty document in the official annals of the Ming Dynasty (Huangming Shilu) conceding that Chinese

http://www.japantimes.co.jp/news/2013/02/01/national/history/curtailed-access-to-chinas-diplomaticarchives-fuels-senkaku-conjecture/\#.VFcOGPTF_xo.

170. The People's Daily article cited by the Japanese Foreign Ministry is entitled "the battle of people in the Ryukyu Islands against U.S. occupation." Press Conference, Assistant Press Secretary, Ministry of Foreign Affairs of Japan (Oct. 2, 2012), available at http://www.mofa.go.jp/announce/press/2012/10/1002_01.html; see also Old China Maps have no Mention of Diaoyu, Only after 1971 did Charts Lay Claim to Japan's Senkaku Islets, JAPAN Times, Dec. 30, 2013, http://www.japantimes.co.jp/news/2013/12/30/national/old-china-maps-have-nomention-of-diaoyu/\#.UsGhvyfRDcx. The Ministry of Foreign Affairs ("MOFA") of Japan frequently updates its analysis. See Situation of the Senkaku Islands, supra note 168.

171. China's official position is laid out in its 2012 White Paper on Diaoyu Dao. State CounCIL InFo. OfFice of China, DiAOYu DAO, AN InHERENT TERRITORy of ChINA (2012), available at http://news.xinhuanet.com/english/china/2012-09/25/c_131872152.htm. The White Paper especially emphasize missions to the Ryukyu Islands (Okinawa) during the Ming Dynasty to confer titles and accept tribute involved passage past Diaoyu Dao, as reflected in the mission records, the role of Diaoyu Dao in China's coastal defense, its inclusion on coastal maps, and the centuries of use by Chinese fishermen. Because of these tribute missions, Chinese nationalist commentators have gone so far as to challenge Japanese sovereignty over Okinawa. China should 'reconsider' who owns Okinawa: academics, BUS. STANDARD (May 8, 2013), http://www.business-standard.com/article/pti-stories/chinashould-reconsider-who-owns-okinawa-academics-113050800900_1.html; Jane Perlez, Calls Grow in China to Press Claim for Okinawa, N.Y. TIMES, June 13, 2013, http://www.nytimes.com/2013/06/14/world/asia/sentiment-builds-in-china-to-press-claim-for-

okinawa.html?pagewanted=all\&_r=0. But China so far has merely allowed publication of such claims in the official press and has not made an official claim. China not Disputing Japan Sovereignty over Okinawa, REUTERS, June 2, 2013, http://uk.reuters.com/article/2013/06/02/uk-security-asia-okinawaidUKBRE95101R20130602.

172. Austin, supra note 95 , at 164.

173. Id. at 165 . 
territorial claims did not reach beyond the Matsu Islands, and thus not as far off shore as the Senkaku/Diaoyu Islands. ${ }^{174}$

Chinese writer Han-yi Shaw attacks the Japanese claim that the islands were terra nullius, citing Japanese contemporary references to Chinese media reports of objections to Japanese surveys beginning in 1885 prior to perfecting the Japanese claimed annexation in $1895 .{ }^{175}$ Such media reportage, however, would likely not be sufficient to establish title, and the cited instances of reaction to such surveys may tend to demonstrate the truthfulness of Japanese claims to perfect their title before their military occupation of Taiwan. ${ }^{176}$ There are certainly a variety of historical claims on both sides that would best be sorted out and evaluated by the ICJ or another agreed arbitral tribunal empowered to resolve the dispute. There is also objection that the 1895 Japanese annexation was not publicized until very recently. $^{177}$

The Chinese agree that the Japanese acquired full sovereignty of the islands in 1895, but argue this was part of the cession of Taiwan in the Treaty of Shimonoseki, which would give rise to the Japanese obligation to return the islands to China after World War II along with the return of Taiwan under the terms of the Japanese Instrument of Surrender and the San Francisco Peace Treaty. ${ }^{178}$ Chinese ownership would first have to have existed for this obligation to arise.

Taiwanese scholar Tao Cheng has sought to bolster the Chinese historical title claim by an irredentist argument that the then contemporary standard of discovery and claim and not the more recent higher standard of "effective occupation" should apply, especially in the context of uninhabited territory. ${ }^{179}$ The policy weakness in this argument is that it goes against the likely anti-colonialist foundation of the "effective occupation" principle, ${ }^{180}$ that great powers not be able to travel the globe, "discover" territory and lay claim with little engagement. A slightly stronger Chinese policy argument, supported by Jon Van Dyke, is that Japan was essentially in its expansionary conquest phase when it claimed the Senkaku/Diaoyu Islands, that the Japanese cabinet decision, even if earlier than the treaty, was essentially part of the same expansionist activity culminating in the Treaty of Shimonoseki, and that such activity should not be recognized as separate and

174. Chinese Document Contradicts Beijing's Claim to Senkakus, Yomiuri SHIMBun, Jan. 23, 2013,__http://www.asianewsnet.net/Chinese-document-contradicts-Beijings-claim-to-Sen-41822.html. Transcriptions of these records are reportedly available in the National Archives of Japan.

175. Han-yi Shaw, The Inconvenient Truth Behind the Diaoyu/Senkaku Islands, N.Y. TimeS, Sept. 19, 2012, http://kristof.blogs.nytimes.com/2012/09/19/the-inconvenient-truth-behind-thediaoyusenkaku-islands/?smid=tw-share.

176. See generally Han-yi Shaw, supra note 158.

177. Id.

178. Id.; Cheng, supra note 86 , at 259-60.

179. See Cheng, supra note 86 , at 224-26. Unryu Suganuma has expressed sympathy for this irredentist argument in respect of claims from the Asian millennia of Pax Sinica, but suggests that Chinese abandonment after their ancient discovery and claim is an open question. See UNRYU Suganuma, SOVEREIGN Rights AND TERRITORIAL SPACE IN SinO-JaPANESE Relations: IRREDENTISM AND THE DIAOYU/SENKAKU IsLANDS 101-115 (Joshua A. Fogel ed., 2000).

180. See generally Cheng, supra note 86. 
distinct. ${ }^{181}$ If accepted, this would strengthen the case that the islands should have been restored to the ROC (Taiwan) after the war. The difficulty is that this claim may simply be counterfactual, if China lacked a valid historical title and the Japanese can prove a sufficient explanation for the 1895 cabinet decision.

Japan disputes both the claim that the Senkaku/Diaoyu Islands were covered by the Treaty of Shimonoseki and the post-war obligation to restore the islands to China. Japanese officials argue that the Japanese cabinet decision annexing the islands occurred three months ahead of the Treaty of Shimonoseki and was unrelated thereto. ${ }^{182}$ They point out that there was no reference to the islands either in the 1895 Treaty of Shimonoseki or the San Francisco Peace Treaty provisions respecting restoration of Taiwan. ${ }^{183}$ Senkaku/Diaoyu Islands are also at some distance from Taiwan, arguing against any presumption of inclusion. ${ }^{184}$ Accordingly, Japan argues that Senkaku/Diaoyu is not included in the reference from the Cairo Declaration incorporated in the San Francisco Peace Treaty requiring that "all territories Japan has stolen . . . be restored to the Republic of China." 185

By Article 3 of the 1951 San Francisco Peace Treaty, Japan further agreed to temporary "exercise of all powers of administration, legislating and jurisdiction" by the United States for the Ryukyu Islands south of twenty-nine degrees north, under which the U.S. took possession of Okinawa and the remaining Ryukyu Islands, as well as the Senkaku/Diaoyu Islands. ${ }^{186}$ The U.S. did not return these islands to Japan until 1972 under the Okinawa Reversion Agreement. ${ }^{187}$ China did not protest the failure to "return" these islands to China along with Taiwan (returned right after World War II) until 1970 — after a 1969 U.N. study reported possibly large oil deposits ${ }^{188}$ - this may be most damning to the Chinese

181. VAN DYKE, supra note 76, at 60-62. Jerome Cohen and Jon Van Dyke have emphasized that Japan fully knew of the Chinese historic claim when they began to take an interest in the islets in 1885 , noting Japanese acknowledgments during the time and the stealth of its cabinet decision, which was not made public until after World War II. Jerome A. Cohen \& Jon M. Van Dyke, Lines of Latitude, S. China Morning Post, Nov.10, 2010, http://www.cfr.org/japan/lines-latitude/p23364. They also express concern about Japan's exaggerated EEZ claim. Id.

182. AUSTIN, supra note 95 , at 168-70.

183. $I d$.

184. 355 kilometers. Distance from Senkaku Islands from Taiwan, GoogLE MAPS (follow "Get Directions" hyperlink; then search "A" for Taiwan and search "B" for "Senkaku Islands"; then follow "Get Directions" hyperlink).

185. AUSTIN, supra note 95, at 170. After the San Francisco Peace Treaty, the ROC on Taiwan entered a peace treaty with Japan that largely reaffirms the provisions of the San Francisco Peace Treaty and expressly nullifies pre-1941 treaties, including the Treaty of Shimonoseki. See Treaty of Peace Between the Republic of China and Japan, China-Japan, Apr. 28, 1952, 139 U.N.T.S. 3. This ROCJapan Peace Treaty makes no mention of Senkaku/Diaoyu. See id. It was promptly renounced by the PRC.

186. Treaty of Peace with Japan, supra note 133, art 3.

187. See Agreement between the United States of America and Japan Concerning the Ryukyu Islands and the Daito Islands, U.S.-Japan, June 17, 1971, 23 U.S.T. 447.

188. AUSTIN, supra note 95 , at 163 . 
position. ${ }^{189}$ After such oil discovery, and just as the islands were slated for return to Japan, China finally filed its protest in $1970 .^{190}$ Both the ROC and PRC likewise objected to the Okinawa Reversion Agreement in 1971 before the reversion was completed. ${ }^{191}$ The first formal point of protest was in 1970; it is when the legal dispute finally crystallized, and would thus likely be viewed as the critical date. ${ }^{192}$ As such, Japan's continuous occupation, including the placement by Japanese citizens of some lighthouse structures, and frequent patrols since that date would not prove ownership. ${ }^{193}$ Likewise, the Japanese government's recent decision to purchase three of the islands from a private title-holder should not have any effect on the merits and would not seem to warrant the sharp response it received. $^{194}$

As is frequently true of remote uninhabited islands, the historical title claims are somewhat murky, though this seems to favor Japan with both the most recent concrete claim and current occupation. The weak link in Japan's claim, as discussed in the next section, is its failure to proclaim that it will not claim resource zones or strait base lines to the islands under UNCLOS. As an archipelagic state under UNCLOS Article 47(1), Japan may typically seek to draw strait baselines to the outer point of its outer islands. ${ }^{195}$ On the other hand, if this is merely an uninhabited rock, as specified in UNCLOS Article 121(3), then the islands should not be entitled to an EEZ or continental shelf. ${ }^{196}$ That the PRC (and Taiwan) traditionally proclaimed that Senkaku/Diaoyu was not entitled to such resource zones may be some indication of Beijing's assessment of the strength of their claim, given that the PRC has not been shy about making extreme maritime claims in the South China Sea. ${ }^{197}$ Such acknowledgement by the PRC also opens the door for Japan to climb down on the issue. Since the PRC is unlikely to agree to a dispute resolution process or formally surrender its claim, without a clear indication from Japan on the resource boundary issue the Senkaku/Diaoyu sovereignty and related resource boundary issues seem likely to remain mired in

189. Id.

190. Id.

191. Statement of the Ministry of Foreign Affairs of the People's Republic of China, 15 PEKING REV. 12, 12 (1972)

192. See Austin, supra note 95 , at 40 .

193. Id. at 9, 40-41; see also Island of Palmas (U.S. v. Neth.), 11 R.I.A.A. 831 (Perm. Ct. Arb. 1925).

194. Japan to Bring Senkaku Islands Under State Control, HoUSE OF JAPAN (Sept. 5, 2012), http://www.houseofjapan.com/local/japan-to-bring-senkaku-islands-under-state-control.

195. UNCLOS, supra note 6 , art. 47, II 1.

196. Id. art. 121, If 3. Bernard Oxman argues this may not be relevant when the rock in question is already within an EEZ, essentially reducing the rock's resource zone implications to it role under the rules on baselines or archipelagic lines. Bernard H. Oxman, On Rocks and Maritime Delimitation, in LOOKING TO THE Future: ESSAYS ON INTERNATIONAL LAW IN HONOR OF W. MichaEL REISMAN (Mahnoush Arsanjani et al. eds., 2010).

197. Recent attempts in September 2012 by the PRC to draw strait baselines around the Diaoyu/Senkaku Islands were roundly criticized by the U.S. U.S. Defense Department criticizes China's claims to Senkaku Islands, JAPAN NEWS, May 8, 2013, http://sinocism.us5.listmanage1.com/track/click?u=f18121 c5942896d3a87491249\&id=ced0683c1f\&e=654fcbfcc5. 
dispute. If that constraint was removed there may be room for forward movement regarding the broader maritime sovereignty and resource claims.

If the resources at stake were reduced by virtue of a Japanese climb-down (to claim only territorial waters) on the resource issue, China may want to reconsider the value of some form of arbitration. When asked to explain the mention of international law and dispute resolution in the September 2012 speech to the U.N. General Assembly by the then Japanese Prime Minister, Japanese officials suggested that, unlike Dokdo/Takeshima, Japan is in full possession of the Senkaku/Diaoyu Islands, such that they have no reason to approach the ICJ. ${ }^{198}$ This statement appears to suggest that if China were to take the case to the ICJ Japan may agree to appear, though this is not expressly said.

As with the above suggestions regarding Japan's possible handling of Dokdo/Takeshima, China may want to consider the value of positive precedent in regard to its relatively stronger claim to the Paracel Islands and parts of the Spratlys in the South China Sea. ${ }^{199}$ A proper dispute resolution process may also allow both governments time to climb down from the nationalistic pressure they now experience over this dispute. A third option would be to designate the island a special international resource protection area without resolving the sovereignty issue. Japanese New Komeito Party leader Natsuo Yamaguchi, during a 2013 official visit to Beijing, offered the more limited proposal of a no-fly zone around the islands. ${ }^{200}$

\section{Associated Resource DisPutes in the SEA of JAPAN AND the EAST ChinA SEA}

Without question, the tension that pervades these disputes over remote uninhabited islands is fueled by the competition for associated resources, though nationalistic sentiments about sovereignty may drive civil society pressures. While not all the resource boundary disputes in the relevant sea areas under discussion bear a direct relationship to the uninhabited island disputes now under discussion, it is undoubted that some seemingly indirect extraordinary claims regarding baselines or the continental shelf may serve as bargaining chips that make settlement of both the island disputes and the maritime resource boundary disputes difficult.

While the spirit of recent years has been to set aside the island sovereignty disputes and attempt to agree on joint resource development zones, this has proven difficult on several levels: first, many resource rights in surrounding seas are

198. Press Conference, supra note 170, II 6.

199. In his comprehensive study Greg Austin favored the Chinese position on the Paracel Islands, and part of the Spratlys. AUSTIN, supra note 95, at 98-158. China has to date essentially refused to entertain discussions on the Paracel Islands. See Greg Torode \& Minnie Chan, China Refuses to Yield on Paracels, S. ChINA MoRnING Post, Dec. 12, 2010, http://www.scmp.com/article/733189/chinarefuses-yield-paracels.

200. See Teddy Ng, Japanese Politician Calls for Disputed Islands no-fly Zone, S. CHINA MORNING POST, Jan. 22, 2013, http://www.scmp.com/news/china/article/1133325/japanese-politiciancalls-disputed-islands-no-fly-zone. 
thought to directly depend on the territorial sovereignty rights to the uninhabited islands; second, at the same time, recent precedent before the UNCLOS Commission on the Limits of the Continental Shelf raises doubts about resource claims for such uninhabited islands; ${ }^{201}$ third, perhaps of greater importance, parties may seek to leverage these island claims against the more extreme claims of their resource competitor respecting base lines or the continental shelf; and, fourth, a background of security concerns and nationalism may make compromise on such territorial sovereignty disputes especially difficult. ${ }^{202}$

\section{A. Japan-Republic of Korea Maritime Disputes}

In the resource area, the Japan-South Korea relationship again offers the most promise for moving forward. Though saddled with a difficult post-colonial and post-war legacy of distrust, robust trade and shared security arrangements in recent decades have fashioned a trade and security partnership less saddled with the tense competition evident in the Sino-Japanese case. Except for some recent flare-ups of tension over Japan's war-time record, shared interest and alignments have historically fostered a degree of moderation over resource claims. Both parties have not appeared to openly attach EEZ or continental shelf resource claims to their Dokdo/Takeshima territorial claims - though this is not absolutely clear, given Japan's tendency to attach such resource zone claims to nearly all small islands in its possession. ${ }^{203}$ The recent UNCLOS Commission Recommendation, rejecting a Japanese claim to an EEZ for an unoccupied island to the East of Japan, would weaken further any effort to claim an EEZ in such context. ${ }^{204}$ South Korea has also sought to match the Chinese natural prolongation argument when it comes to the continental shelf toward Japan, but one may question how serious South Korea can ultimately be about this in the face of the contrary UNCLOS jurisprudence noted above.

With a somewhat less tense relationship over past years, the parties have reached a number of agreements. They were able in 1974 (which came into force in 1978, well before UNCLOS) to reach two agreements concerning the continental shelf: one is the only boundary agreement ever reached in Northeast

201. COMM'N ON THE Limits OF THE CONTINENTAL SHELF, SuMMARY OF RECOMMENDATIONS OF THE COMMISSION ON THE Limits OF THE CONTINENTAL SHELF IN REgaRd TO THE SubMission MADE BY JAPAN ON 12 NOVEMBER 2008, para. 20 (2012), available at http://www.un.org/Depts/los/clcs_new/submissions_files/jpn08/com_sumrec_jpn_fin.pdf [hereinafter Commission Recommendation]. Regarding the uninhabited island of Okinotorishima the Commission, in the face of Chinese and South Korean objection to Japan's resource claims, refused to make a recommendation. While this set no precedent on the substantive issue, which presumably would have to be submitted to a proper tribunal, it did offer a UN based statement of skepticism regarding such claims. See UN Approves Japan's Claim on Wider Seas, Yomiuri Shimbun/Asia News Network, Apr. 29, 2012, http://www.asiaone.com/News/AsiaOne\%2BNews/Asia/Story/A1Story20120429342721.html.

202. South Korea has resource boundary disputes with China and even more difficult and volatile maritime boundary issues with North Korea, which are beyond the scope of the present essay.

203. VAN DYKE, supra note 76, at 51-52.

204. See Commission Recommendation, supra note 201. 
Asia, delimiting a median line continental shelf boundary in the northern part of the Korea Strait (named the "Tsushima Strait" in Japan), ${ }^{205}$ the other is the 1974 (came into effect in 1978) joint development agreement for areas of the East China Sea south of Cheju Island bounded by the outer limits of their overlapping claims. $^{206}$ China has objected that the resultant joint development zone overreaches into Chinese areas and it remains for the two partners to reach agreement with China. ${ }^{207}$ The Joint Development Zone agreement provides for joint development of resources from the continental shelf in an approximately 24,000 square nautical mile area where the parties' continental shelf claims overlap in the East China Sea below Cheju Island and has a mandatory period of fifty years. $^{208}$

The resultant Joint Development Zone is mostly on the Japanese side of the median because Japan is claiming up to the median line and South Korea is claiming natural prolongation beyond the median line. This generous preUNCLOS Japanese agreement may have inspired China to demand similar concessions in its resource dispute with Japan, even though UNCLOS now offers no support in this context for China's natural prolongation argument. With the respective continental shelf boundaries between Japan and South Korea not yet resolved this seeming unfairness may require future adjustment in the joint development zone if a boundary settlement is ultimately reached around the median line approach now favored under UNCLOS. North of the Korea Strait, below any area where North Korean maritime claims are implicated, equidistant lines should adequately deal with the resource boundary disputes in the Sea of Japan, once the Dokdo/Takeshima issue is resolved.

In 1998, Japan and South Korea also reached a fisheries agreement, which seeks to set aside boundary disputes and accommodate differences over Dokdo/Takeshima. ${ }^{209}$ The agreement is a "provisional agreement" under UNCLOS Article 74(3) pending final determination of maritime boundaries and should have little effect on the territorial or maritime disputes now pending. Since UNCLOS would favor fisheries access agreements to properly maintain fishing stock in EEZs, ${ }^{210}$ fishery agreements are more easily achieved and may be sustainable even after resolution of boundary issues. Japan's excessive use of

205. Choon-Ho Park, Seabed Boundary Issues in the East China Sea, in SEABed Petroleum IN NORTHEAST ASIA: CONFLICT OR COOPERATION 19, 19-22 (Selig S. Harrison ed., 2005).

206. Id. at $19-20$.

207. Id. at 21.

208. Id. at 20.

209. Agreement Between Japan and the Republic of Korean Concerning Fisheries, Japan-S. Kor., Nov. 28, 1998, I-48295. See Pilkyu Kim, supra note 86, at 28-30.

210. See Marcos A. Orellana, EEZ Fisheries Access Arrangements and the WTO Subsidies Agreement, in Promoting Sustainable Fisheries, The InTERnational Legal and Policy FRAMEWORK TO COMBAT ILLEGAL, UNREPORTED AND UNREGULATED Fishing (Mary Ann Palma et al. eds., 2010); U.N. ENVIRONMENT PROGRAmme, UNEP IN $2007 \quad 6$ (2007), available at http://www.unep.org/PDF/AnnualReport/2007/AnnualReport2007_en_web.pdf. 
strait baselines continues to pose some difficulty in Japan-South Korean discussions in this regard. ${ }^{211}$

\section{B. China-Japan Maritime Disputes}

The Sino-Japanese maritime resource boundary discussions are far more difficult and clearly implicate the Senkaku/Diaoyu Islands dispute. Japan has long unilaterally designated a median line in the East China Sea between China and Japan as the appropriate boundary for both the EEZ and the continental shelf resources zones. ${ }^{212}$ The most difficult obstacle to any effort to reach an equitable solution has been the Chinese claim to nearly all of the continental shelf between China and the Japanese islands on the basis of natural prolongation. ${ }^{213}$ As discussed above, recent case law in the ICJ clearly makes such an extreme claim untenable for opposite states within $400 \mathrm{~nm}$ of each other. ${ }^{214}$

Another major obstacle to mutual accommodation is the tendency of both China and Japan to make excessive use of strait baselines. Before the parties can start discussion around an initial median line, there must be some consensus on the base lines from which the median line would be drawn. Since Japan's baselines to the south will be those typical of an archipelago, along the Ryukyu Islands, Japan is expected to use strait baselines to the outermost points of the outermost island. ${ }^{215}$ Such lines should generally not exceed $100 \mathrm{~nm}$ and "should not depart to any appreciable extent from the general configuration of the archipelago."216 This would seemingly render any attempt to draw a strait baseline from the Japanese Ryukyu Islands to the uninhabited Senkaku/Diaoyu Islands inappropriate.

The most egregious current Chinese baseline claim should also be dropped: China's strait baselines to the uninhabited high tide elevation called Dongdao Island some seventy miles offshore from Shanghai. ${ }^{217}$ It is possible that such an extraordinary baseline claim is envisioned as a bargaining chip. Perhaps China may be persuaded to drop this baseline claim if Japan disavowed any claim to any

211. VAN DYKE, supra note 76, at 44-45.

212. See Peterson, supra note 92; Kosuke Takahashi, Gas and Oil Rivalry in the East China Sea, ASIA TIMES ONLINE (July 27, 2004), http://www.atimes.com/atimes/Japan/FG27Dh03.html.

213. The Chinese Foreign Minister Yang Jiechi stated, "On the East China Sea delimitation, China has never and will not recognize the so-called 'median line' as advocated by Japan. China upholds the principle of natural prolongation to solve the delimitation issue of the East China Sea continental shelf." Chinese Agency, Tentative Translation of FM's Answers on East China Sea Issue, XINHUA NEws AGENCY, June 24, 2008, quoted in Peterson, supra note 91, at 454, n.137. China has submitted this continental shelf prolongation to the U.N. in a submission entitled "Partial Submission Concerning the Outer Limits of the Continental Shelf beyond 200nm in the East China Sea." China Makes U.N. Appeal for Maritime Claim, UPI, Dec. 18, 2012, http://www.upi.com/Top_News/Special/2012/12/17/Chinamakes-UN-appeal-for-maritime-claim/UPI-60871355720880/.

214. See VAN DYKE, supra note 76, at 58; Continental Shelf (Libya v. Malta), 1985 I.C.J. 13, at 35, II 39 (June 3).

215. UNCLOS, supra note 6 , art. 47, II 1.

216. Id. art. 47, III 2-3.

217. See Bureau of Ocean and InT'L Envtl. And Scientific AfFairs, U.S. DeP'T of State, Pub. No. 117, Straight Baseline Claim: China (1996). 
extended baselines from the Ryukyu Islands to Senkaku/Diaoyu, as well as claim to any resource zones around the Senkaku/Diaoyu Islands. Both claims would appear untenable under UNCLOS as currently interpreted. If proper baselines were agreed upon and the parties could identify an initial equidistant or median line, they would still be left with the question of proportionality. ${ }^{218}$ This is important, because the larger hydrocarbon reserves are thought to be on the Japanese side of the median line. ${ }^{219}$

As discussed above, a tribunal trying to resolve the Sino-Japanese maritime boundary dispute would likely begin with equidistant or median lines and then adjust such lines to achieve proportionality between the relative length of the two opposing coastlines and the resource zone allocated. ${ }^{220}$ The actual Chinese coast is clearly much longer than the Japanese coastal areas along the Ryukyu Island chain, which covers most of the area opposite China's coast. Using its natural prolongation claim, China has sought to claim all the continental shelf to the Eastern side of the deep Okinawa Trough that borders the Ryukyu Islands. ${ }^{221}$ China is thought to be motivated in this regard because the petroleum deposits in the Okinawa Trough are reportedly the richest in the East China Sea. ${ }^{22}$ Using the appropriate equitable solution and proportionality standards, one suspects the boundary line would still fall on the Western side of the Okinawa Trough toward China, though a proportionality analysis would bring more resources on to the Chinese side of the boundary than a simple median line. ${ }^{223}$

In spite of these interconnected difficulties, China and Japan in 1997 reached a fisheries agreement, covering areas above twenty-seven degrees north, from a point about one hundred kilometers north of the Senkaku/Diaoyu Islands. ${ }^{224}$ This fisheries agreement is rather comprehensive, identifying four fishing zones, including undisputed territorial seas, exclusive fishing zones within EEZs, shared zones in EEZs straddling median lines, and high seas; there is also provision for mutual access to EEZs, fishing quotas, a Joint Fisheries Commission and conservation measures. ${ }^{25}$ The exclusion of the Senkaku/Diaoyu area from coverage has left a big gap to generate troubled disputes, such as was evident in 2010 over Japanese arrest of Chinese fishermen for ramming the Japanese patrol boat near the Senkaku/Diaoyu Islands and again in the arrest of 13 occupiers in $2012 .^{226}$

218. See Continental Shelf, 1985 I.C.J. 13

219. Choon-Ho Park, supra note 205, at 5-6.

220. Continental Shelf, 1985 I.C.J. 13.

221. VAN DYKE, supra note 76, at 58-60.

222. Choon-Ho Park, supra note 205, at 6.

223. VAN DYKE, supra note 76, at 58-60.

224. See Zou, supra note 79, at 132-40; Nobukatsu Kanehara \& Arima Yutaka, Japan's New Agreement on Fisheries with the Republic of Korea and the People's Republic of China, 42 JAPANESE ANN. OF INT'L L. 1, 1-31 (1999); Zhiguo GaO \& JiLu Wu, Key ISSUES IN the EAST China SEA: A STATUS REPORT AND RECOMMENDED APPROACHES 5, available at http://www.wilsoncenter.org/sites/default/files/Zhiguo_Gao_and_Jilu_Wu.pdf.

225. Zou, supra note 79, at 132-40.

226. See Tanaka Sakai, Rekindling China-Japan Conflict: The Senkaku/ 
Agreement over the valuable petroleum deposits has proven much more difficult due to the value of the resources involved and the troubled boundary delimitation disputes noted above. China had generally sought to have any joint development zones located entirely on the Japanese side of Japan's proposed median line, arguing that the continental shelf on the East side of the line is the only part in dispute - tracking more or less the pre-UNCLOS resource zone as was agreed between Japan and South Korea. ${ }^{227}$ Moderate progress was achieved when China and Japan announced on June 18, 2008, in separate press conferences, a "principled consensus" to jointly explore and develop natural resources in a 2,700 square kilometer area in the East China Sea that straddles Japan's proposed median line well to the north of Senkaku/Diaoyu Islands. ${ }^{228}$ The arrangement also appears to authorize Japanese corporations to invest in the existing Chinese-operated Chunxiao oil and gas field bordering the median line on the Chinese side. ${ }^{229}$ The stated objectives of this "principled consensus" have not been implemented, and Japan continues to protest that the Chinese drilling near the median line will siphon off petroleum from the Japanese side. ${ }^{230}$ Given the peculiarities of the separate announcement and continued discussions over full implementation, there is good reason to doubt that the "principled consensus" rises to the level of an actual agreement. As indicated in the Japanese press statement, the parties appear to view it as a principled consensus to work toward realizing an enforceable agreement. $^{231}$ It seemingly envisions joint resource exploration and possible, though yet unrealized, shared production. ${ }^{232}$ In fact, continued discussions broke down during the 2010 dispute over the Japanese arrest of Chinese fishermen near the Senkaku/Diaoyu Islands. ${ }^{233}$

Though the process has been too opaque for a clear reading, it appears the chief obstacles to further agreement have been the problematic baselines, China's excessive natural prolongation claim regarding the continental shelf and the dispute over Senkaku/Diaoyu, especially Japan's failure to formally acknowledge

Diaoyutai Islands Clash, ASIA-PACIFIC J.: JAPAN FOCUS (Sept. 27, 2010), http://japanfocus.org/Tanaka-Sakai/3418.

227. See Susumu Yarita, Toward Cooperation in the East China SEa 2 (2005), available at http://www.wilsoncenter.org/sites/default/files/Susumu_Yarita.pdf (discussing how the pre-1982 JapanSouth Korean agreement plays a part in China's attempt to advance such seemingly unjustified claim).

228. Press Release, Ministry of Foreign Affairs of the People's Republic of China, China and Japan Reach Principled Consensus on East China Sea Issue (June 18, 2008), available at http://nz.chinaembassy.org/eng/xw/t466729.htm [hereinafter Japan Press Release]; Joint Press Conference, Ministry of Foreign Affairs of Japan, Minister of Foreign Affairs Masahiko Koumura and Minister of Economy, Trade and Industry Akira Mari, Regarding Cooperation Between Japan and China in the East China

Sea (June 18, 2008, 6:25 PM), available at http://www.mofa.go.jp/announce/fm_press/2008/6/0618.html.

229. Japan Press Release, supra note 228.

230. See Choon-Ho Park, supra note 205, at 3-5; Mari Yamaguchi, Japan Protests to China over Undersea Gas Drilling, AsSOCIATED PRESS, Feb. 1, 2012, http://news.yahoo.com/japan-protests-chinaover-undersea-gas-drilling-022110278.html.

231. Japan Press Release, supra note 228. See Peterson, supra note 91, at 465-70.

232. Japanese Press Release, supra note 228.

233. Fackler, supra note 8. 
that it would not be entitled to resource zones and extended baselines. Agreement on baselines should be generally achievable through give and take with reference to UNCLOS. On the continental shelf claims, China has historically argued that any provisional cooperative agreement for joint development under UNCLOS should only apply to the Japanese side of the median line since that is the only disputed area. ${ }^{234}$ This is extraordinary in that China is using an excessive indefensible claim against the relatively moderate Japanese continental shelf claim to effectively say, what is mine is mine and what is yours is ours. That the rather limited "principled consensus" to date involves resource areas on both sides of the median line perhaps reveals that the Chinese understand how untenable their more extreme natural prolongation claim to the entire continental shelf is.

On Senkaku/Diaoyu resource claims, China has already acknowledged that the islands do not warrant resource zones, though it seemingly has not conceded the strait baseline point should it prevail in its claim to the islands. If there is any room for movement it would seem that Japan might be persuaded to abandon resource and baseline claims over Senkaku/Diaoyu if China were to drop its excessive baseline claim for Dungdao Island or other behind-the-scenes "bargaining chips." The above noted UNCLOS Commission Recommendation rejecting a similar claim for an extended continental shelf would seem to make this shift tenable. $^{235}$

In general, similar strait baseline excesses on both sides could be modified in any deal to achieve equity. In doing so, both sides would not realistically be giving up anything and would simply be following established international law, as required by UNCLOS. If the parties could then quietly begin discussions of resource boundaries based on the established UNCLOS rules regarding equidistance and proportionality, it would seem that an equitable solution would be within reach over the entire East China Sea. Japan's dropping of any resource zone claims for the Senkaku/Diaoyu Islands might be the proverbial log to be gently pulled out to relax the impasse. The Senkaku/Diaoyu Islands should only be entitled to a territorial sea of $12 \mathrm{~nm}$ or less.

\section{Security Concerns}

The seas as a resource also include the maritime role in security and the question of military passage. ${ }^{236}$ In the coastal resource zones, the coastal state usually has complete control over living and nonliving resources and can limit marine scientific research, but other states otherwise retain normal rights associated with the high seas and air passage over international waters. ${ }^{237}$ In this regard, UNCLOS protects freedom of navigation for military and commercial passage by ships of other countries through such zones, an issue about which

234. YARITA, supra note 227.

235. See Commission Recommendation, supra note 201.

236. Id. at 26; Y.H. Song, China and the Military Use of the Ocean, 21 OCEAN DEV. AND INT'L L. 221, 226 (1990).

237. UNCLOS, supra note 6 , arts. 56,58 . 
China has some objections. ${ }^{238}$ Associated military surveillance activities are usually thought to be protected activity, as it is allowed on the high seas more generally.

China has especially objected to U.S. military activities in the area, ${ }^{239}$ including hydrographic surveys by U.S. military ships in China's EEZ, surveys that the U.S. argues are in furtherance of submarine navigation. ${ }^{240}$ China characterizes such passage and seabed surveys as marine scientific research, which would require China's permission under UNCLOS. ${ }^{241}$ While participating in the Rim of the Pacific ("RIMPAC") maritime exercise, China was reported to be spying on the so-called "Rim Pac" exercises off Hawaii in the U.S. EEZ, which raises the question whether China will continue to object to surveillance activity in its EEZ. ${ }^{242}$ China's recent proclamation of an ADIZ across much of the area between China and Japan beyond China's EEZ is thought to have dual purpose of seizing control over the air above disputed islands and also constraining surveillance flights through the area. ${ }^{243}$ The U.S. argues the naval sea and air hydrographic and military surveys are permitted under in the UNCLOS convention and that the surveillance flights above international waters are unrestricted. ${ }^{244}$ On that basis, the U.S. likewise did not object to the Chinese ship surveillance in the U.S. EEZ during RIMPAC.

This question of military passage and surveillance has caused confrontation between the U.S. and China several times in recent years. ${ }^{245}$ Such incidents have included a Chinese air crash and the forced landing of a U.S. plane on Hainan

238. Id. $\S 3$.

239. Mark Valencia, China and US must agree on rules for waters in exclusive economic zone, S. CHINA MORNING POST, Aug. 31, 2013, http://www.scmp.com/comment/insightopinion/article/1300695/china-and-us-must-agree-rules-waters-exclusive-economic-zone ("[T]he deployment and use of any type of scientific research equipment in any area of the marine environment shall be subject to the same conditions ... for the conduct of marine scientific research in any such area.").

240. Id.

241. Id.; UNCLOS, supra note 6, art. 21.

242. China defends dispatch of spy ship to monitor US-led naval drills off Hawaii, S. CHINA MoRNING POST, July 21, 2014, http://www.scmp.com/news/world/article/1556956/chinese-spy-shipmonitors-us-led-naval-drills-hawaii; Andrew Erickson \& Emily de La Bruyere, Crashing Its Own Party: China's Unusual Decision to Spy on Joint Naval Exercises, WALL ST. J., July 19, 2014, http://blogs.wsj.com/chinarealtime/2014/07/19/crashing-its-own-party-chinas-unusual-decision-to-spyon-joint-naval-exercises/?mod=chinablog; Kristine Kwok, China hostility to surveillance may lessen as it becomes a maritime power, S. CHINA MORNING POsT , Jan. 6, 2014, http://www.scmp.com/news/china/article/1398413/china-hostility-surveillance-may-lessen-it-becomesmaritime-power.

243. See Jun Osawa, China's ADIZ over the East China Sea: A "Great Wall in the Sky"?, BROOKINGS (Dec. 17, 2013), http://www.brookings.edu/research/opinions/2013/12/17-china-airdefense-identification-zone-osawa.

244. Valencia, supra note 239.

245. Li Jing, United States and Chinese Warships nearly Collide in South China Sea, S. CHINA MornING Post, Oct. 17, 2014, http://www.scmp.com/news/china/article/1380830/united-states-andchinese-warships-nearly-collide-south-china-sea. 
Island in $2001,{ }^{246}$ Chinese damage to sonar equipment on the U.S.S. Impeccable engaged in monitoring of Chinese submarines in the EEZ off Hainan Island in $2009,{ }^{247}$ and the controversy over joint US-South Korean exercises in the Yellow Sea in 2010, where the Chinese objected to the presence of U.S. warships. ${ }^{248}$ That the U.S. has defense agreements with nearly all countries surrounding Senkaku/Diaoyu Island and that it has reiterated the inclusion of these islands as part of its commitment to defend Japanese administered territory emphasizes the connection of disputes over the islands and resources to the U.S. perception of overall security volatility in the area. ${ }^{249}$

The combination of the U.S. "pivot" toward Asia, China's increased projection of power in the region, and the expanded military buildup by Japan and the Philippines predicts continued volatility over these security issues. ${ }^{250}$ U.S. involvement may serve to check Chinese military aggression but it also adds increased risk of miscalculation. ${ }^{251}$ That China engages in increased military activity offshore from Japan, the Philippines, and Vietnam, and is sometimes suspected of using poorly identified fishing boats in security roles, adds to the volatility of its various island disputes. ${ }^{252}$

Some analysts believe China's heightened belligerence, especially with Japan, may reflect the leadership's aim to create a more confrontational environment in which to whip China's largely untested PLA into shape. ${ }^{253}$ Japanese Admiral Fumio Ota sees Chinese military intrusion into Japanese EEZs, in combination with the lack of transparency concerning China's military build-up and activities, as having the highest risk of occurrence among Sino-Japanese conflict risks. ${ }^{254}$

246. Elizabeth Rosenthal, US Plane in China After it Collides with Chinese Jet, N.Y. TIMES, Apr. 2, 2001, http://www.nytimes.com/2001/04/02/world/us-plane-in-china-after-it-collides-with-chinesejet.html.

247. Jane Perlez, American and Chinese Navy Ships Nearly Collided in South China Sea, N,Y. TIMES, Dec. 14，2013，http://www.nytimes.com/2013/12/15/world/asia/chinese-and-american-shipsnearly-collide-in-south-china-sea.html

248. Jerome A Cohen \& Jon M. Van Dyke, Limits of Tolerance, S. ChInA Morning Post, Dec. 7, 2010, http://www.cfr.org/china/limits-tolerance/p23593. In December 2002 China even passed a law requiring Chinese approval of mapping and surveying activities in its EEZ. Id.

249. Cary Huang, Why China is wary of US stepping in over Diaoyus, S. CHINA MoRnING PosT, Nov. 1, 2010, http://www.scmp.com/article/729128/why-china-wary-us-stepping-over-diaoyus; Greg Torode, US Naval Chief Warns of 'Winds of Change', S. ChINA MoRnING Post, Sept. 13, 2010, http://www.viet-studies.info/kinhte/Winds_of_Change.htm.

250. Stephen M. Walt, Explaining Obama's Asia policy, ForeIGn POL'Y, Nov. 18, 2011, http://walt.foreignpolicy.com/posts/2011/11/18/explaining_obamas_asia_policy.

251. Chi-Chi Zang, China Objects to US Offer Over Disputed Islands, Associated Press, Nov. 3 , 2010, http://www.washingtonpost.com/wp-dyn/content/article/2010/11/02/AR2010110200908.html; Cheng Guangjin, Beijing Rejects US Offer to Host Diaoyu Talks, ChINA DAILY, Nov. 3, 2010, http://usa.chinadaily.com.cn/2010-11/03/content_11495897.htm.

252. Edward Wong, Chinese Civilian Boats Roil Disputed Waters, N.Y. TIMES, Oct. 5, 2010, http://www.nytimes.com/2010/10/06/world/asia/06beijing.html?_r=0.

253. John Garnaut, Leader's Ploy More than Naval Gazing, Sydney Morning Herald, Apr. 27, 2013, http://www.smh.com.au/world/leaders-ploy-more-than-naval-gazing-20130426-2ijxx.html.

254. Fumio Ota, Conflict Prevention and Confidence Building Measures Between Japan and China, INT'L ASSESSMENT AND STRATEGY CTR. (Jan. 5, 2009), 
Query whether this lends support to Japanese suspicions about greater Chinese ambitions beyond the Senkaku/Diaoyu Islands to the Ryukyu Islands (Okinawa), which China treated as a tributary kingdom for five hundred years before the Japanese annexation in $1879 ?^{255}$

\section{CONCLUSION}

The above overview has exposed the two sets of island disputes as a cause that has soured relations between the three protagonists (along with the ROC on Taiwan and the United States) for the last half-century. This article has sought to show that a series of contingent relationships between various island and resource claims have led the parties to cling to various claims as bargaining chips in a dispute process defined by bluster and excess. As long as the parties were content to defer resolution of these disputes for another time as they set about the process of trade and development this standoff or log-jam may have been optimal. But with increasing resource scarcity brought on by rapid economic development in the region and increasing security ambitions by a rapidly developing China, this standoff has become untenable and a serious security risk. If one adds to this mix the nationalistic passions that these contests over sovereignty have caused the danger of miscalculation leading to military confrontation becomes even more evident.

The good news is that these problems are solvable far short of military confrontation. Since the parties engaged these issues in the early 1970s, considerable international legal principles have developed either through treaty law or international case precedent in the ICJ. Such legal principles offer the parties substantial guidance on nearly all of the contentious issues, including: appropriate baseline delineation, ${ }^{256}$ the use of the equidistant principles, ${ }^{257}$ proportionality, ${ }^{258}$ equitable boundaries for maritime resources, ${ }^{259}$ the standards for territorial disputes and historical title in the context of disputes over uninhabited islands, ${ }^{260}$ and the

http://www.strategycenter.net/research/pubID.192/pub_detail.asp. Ota identifies three conflict scenarios, including possible Taiwan Strait conflict (which he rates as high intensity, low probability); potential conflict over Senkaku/Diaoyu (middle intensity, middle probability) and Chinese surveillance activity in the Japanese EEZ (low intensity, high probability). Id.; Lifeng Jiang, Some Advice for Japan, CHINA DAILY, Nov. 4, 2010, http://www.chinadaily.com.cn/opinion/201011/04/content_11500095.htm. Admiral Ota suggests better crisis management strategies. Chinese scholar Lifeng Jiang appears to concur in the need for improved Sino-Japanese crisis management strategies. Id.

255. Chinese Nationalists Covet Japan's Okinawa, S. ChINA MoRnING Post, Oct. 14, 2012, http://www.scmp.com/news/china/article/1057756/chinese-nationalists-covet-japans-okinawa. Chinese state-owned media have in fact raised question regarding the legitimacy of Japanese sovereignty over Okinawa. $I d$.

256. UNCLOS, supra note 6, art. 7.

257. Id. arts. 74,83 .

258. Continental Shelf (Libya v. Malta), 1985 I.C.J. 13 (June 3); VAN DYKE, supra note 76, at 59.

259. UNCLOS, supra note 6 , arts. 74, 76, 83.

260. See VAN DYKE, supra note 76, at 47-49, 61 (citing a series of cases); Austin, supra note 96, at $36-40$. 
allocation of resource zones around such uninhabitable islands. ${ }^{261}$ Given that the past practice of ignoring the island disputes and trying to reach resource agreements has not worked, this article offers a contrarian view that the island disputes may be the proverbial logs jamming up the process and recommends that attention to these issues be prioritized.

Both the island disputes can be taken off the table, either by complete resolution, as seems tenable in the case of Dokdo/Takeshima, or by abandoning resource zone claims, as is clearly called for in respect of Senkaku/Diaoyu. An even better, though unlikely, solution to the latter would be for China to take up Japan's somewhat ambiguous invitation to present the matter to the ICJ. Presumably, none of the parties would want to be seen by their nationals to simply surrender the islands they claim. In the case of Dokdo/Takeshima, the somewhat lesser nationalistic sentiments on this particular claim on the Japanese side has allowed Japan to propose referral to the ICJ. South Korea should take advantage of this opening. The South Korean argument that this is a matter of sovereignty that cannot be submitted to the ICJ is indefensible. The many territorial disputes that make up the bulk of ICJ cases in this area cited herein are all sovereignty disputes. As has been evident in past compromises over fisheries and joint development zones, compromise is something both Japan and South Korea are capable of.

With the Dokdo/Takeshima dispute out of the way and a reasonable willingness to adhere to the UNCLOS requirements to apply established international legal standards towards agreeing on equitable solutions-including baselines and proportional resource allocation-chances are good that all such issues between South Korea and Japan could be solved. It would then be up to the parties, as a matter of prudence, to favor either cooperative arrangements or resource boundary delineation and separate development. It could then be hoped that the approach taken and the standards set may have some effect on the parties' ability to reach compromise with China on other island and resource issues. Cooperative resource development should be about economic development and efficiency and not simply a way of avoiding the equitable solutions specified by UNCLOS. Having needed resources available for commercial harvesting in the region may be more important than who owns the underlying right.

It has to be acknowledged that it may be more difficult to reach final resolution of the Senkaku/Diaoyu sovereignty dispute. It appears civil society on both sides have displayed an enhanced level of nationalism over this issue, making compromise on sovereignty difficult. At the same time, China has long been reluctant to agree to arbitration for matters of this sort. What may be more realistic is to find a way to trim back the resource issues that are implicated. This is the log that can be gently removed from the log-jam if the parties can honestly understand the bargaining chips they have deployed. The most obvious bargain would be Japanese acknowledgment that the islands are entitled under UNCLOS neither to resource zones nor strait baseline inclusion in the Ryukyu Islands. At the same

261. UNCLOS, supra note 6, art. 121(3). 
time the Chinese side must appreciate that Dongdao Island is likewise not entitled to strait baseline inclusion. Beyond these two cases, there are other baseline issues offering room for equitable tradeoffs. While solving the Senkaku/Diaoyu dispute fully as suggested for Dokdo/Takeshima may be an optimal first choice, trimming back the island dispute to acknowledge resource irrelevance is a good second-best alternative that would be consistent with the parties' international legal obligations. Perhaps then designating the islands a joint special resource conservation zone may diminish the nationalistic sensitivities. ${ }^{262}$

International legal obligations, when it comes to delineating continental shelf rights, likewise clearly require agreement on an equitable solution based on a mix of equidistant lines and proportionality. The relevant baselines from which these principles would be applied have also been made relatively clear by UNCLOS jurisprudence. While both sides would likely have to surrender some of the resources they would hope for, the resolution of these disputes would surely pay great dividends in allowing nearby undersea resources to be commercially developed. The parties would need to decide whether to go the joint development or boundary delineation route. One would hope the recent improved relations between Taiwan and the mainland of China would allow appropriate sharing of whatever benefit was achieved from the Sino-Japanese progress on these sensitive issues. If trimmed back for resource purposes, perhaps the Senkaku/Diaoyu Islands could simply be designated as a joint bird sanctuary with jointly managed fishing rights in conjunction with agreements concerning adjoining areas, as seems appropriate for friendly neighboring countries.

Finally, it should be borne in mind that moving forward in Northeast Asia may provide a more coherent standard for moving forward on the island disputes in the South China Sea. Some leading scholarly opinion favors China on parts of the Paracel Islands and multiple claimants on the Spratlys. If underlying international legal standards are teased out first between South Korea and Japan, and then between China and Japan, such resolution may provide precedent for a more fruitful effort to resolve similar disputes in the South China Sea. Pulling various logs from the log-jam may make further progress in its removal possible. At a minimum, any party that refuses to follow the clearly emerging international legal standards, who clings to excessive bargaining chips, would be exposed and have to bear the diplomatic cost.

262. Ian Story, ASEAN and the South China Sea: Movement in Lieu of Progress, 12 CHINA BRIEF 10, $10 \quad$ (2012), available
http://www.jamestown.org/single/?tx_ttnews[tt_news]=39305\#.VGD8_8mRM5c. It is interesting to note that the Philippine government has suggested something similar regarding disputed islands in the South China Sea, or what the Philippines calls the West Philippine Sea, suggesting they be designated a "Zone of Peace, Freedom, Friendship and Cooperation," with accompanying de-militarization and a joint agency to manage seabed resources and fisheries. Id. 